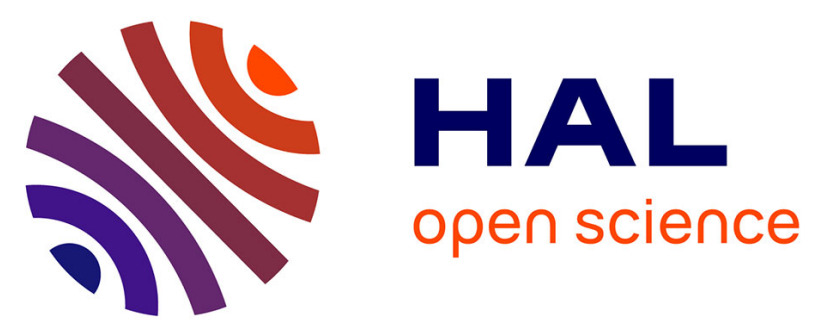

\title{
Understanding groundwater systems and their functioning through the study of stable water isotopes in a hard-rock aquifer (Maheshwaram watershed, India) Philippe Négrel, Hélène Pauwels, Benoît Dewandel, Jean-Marie Gandolfi, Cédric Mascré, Mohamed-Salem Ahmed
}

\section{To cite this version:}

Philippe Négrel, Hélène Pauwels, Benoît Dewandel, Jean-Marie Gandolfi, Cédric Mascré, et al.. Understanding groundwater systems and their functioning through the study of stable water isotopes in a hard-rock aquifer (Maheshwaram watershed, India). Journal of Hydrology, 2011, 397 (1-2), pp.55-70. 10.1016/j.jhydrol.2010.11.033 . hal-00552062

\section{HAL Id: hal-00552062 https://hal-brgm.archives-ouvertes.fr/hal-00552062}

Submitted on 5 Jan 2011

HAL is a multi-disciplinary open access archive for the deposit and dissemination of scientific research documents, whether they are published or not. The documents may come from teaching and research institutions in France or abroad, or from public or private research centers.
L'archive ouverte pluridisciplinaire HAL, est destinée au dépôt et à la diffusion de documents scientifiques de niveau recherche, publiés ou non, émanant des établissements d'enseignement et de recherche français ou étrangers, des laboratoires publics ou privés. 


\title{
UNDERSTANDING GROUNDWATER SYSTEMS AND THEIR FUNCTIONING THROUGH THE STUDY OF STABLE WATER ISOTOPES IN A HARD-ROCK AQUIFER (MAHESHWARAM WATERSHED, INDIA)
}

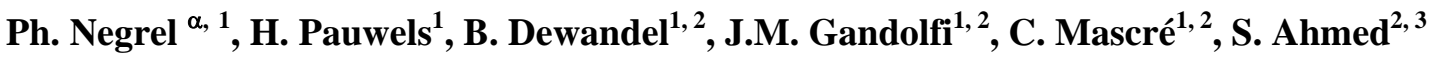 \\ ${ }^{1}$ BRGM, Avenue C. Guillemin, BP 36009, 45060 Orléans Cedex 02, FRANCE.

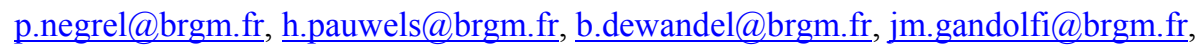 \\ ${ }^{2}$ CEFIRES, Indo-French Center for Ground water Research, NGRI, Uppal Road, 500007 Hyderabad, India \\ ${ }^{3}$ NGRI, Uppal Road, 500007 Hyderabad, India
}

\section{Abstract}

Groundwater degradation through abstraction, contamination, etc., shows a world-wide increase and has been of growing concern for the past decades. In this light, the stable isotopes of the water molecule $\left(\delta^{18} \mathrm{O}\right.$ and $\left.\delta^{2} \mathrm{H}\right)$ from a hard-rock aquifer in the Maheshwaram watershed (Andhra Pradesh, India) were studied. This small watershed $\left(53 \mathrm{~km}^{2}\right)$ underlain by granite, is endorheic and representative of agricultural land use in India, with more than 700 bore wells in use. In such a watershed, the effect of overpumping can be severe and the environmental effects of water abstraction and contamination are of vital importance. A detailed and dynamic understanding of groundwater sources and flow paths in this watershed thus is a major issue for both researchers and water managers, especially with regards to water quality as well as the delimitation of resources and long-term sustainability.

To this end, the input from monsoon-precipitation was monitored over two cycles, as well as measuring spatial and temporal variations in $\delta^{18} \mathrm{O}$ and $\delta^{2} \mathrm{H}$ in the groundwater and in precipitation. Individual recharge from the two monsoon periods was identified, leading to identification of periods during which evaporation affects groundwater quality through a higher concentration of salts and stable isotopes in the return flow. Such evaporation is further affected by land use, rice paddies having the strongest evapotranspiration.

\footnotetext{
${ }^{\alpha}$ Corresponding author: p.negrel@brgm.fr; Tel.: +33 2386439 69, Fax: +33 238643446
} 
Keywords: Evaporation, Groundwater, India, Monsoon, Recharge, Stable Isotopes 


\section{Introduction}

Groundwater flow and storage in hard-rock areas are of great interest and importance to researchers and water managers (e.g., De Silva and Weatherhead, 1997; Ballukraya and Sakthivadivel, 2002), from a viewpoint of both water quantity (Gupta and Singh, 1988) and quality (Robins and Smedley, 1994), as well as for delimiting resources and aquifers (e.g., Singhal et al., 1988). In terms of hydrogeology, hard rocks are heterogeneous and anisotropic, groundwater flow generally being controlled by fissure networks (Maréchal et al., 2004).

Typically, hard-rock aquifers occupy the first tens of metres below ground (Detay et al., 1989). Their hydrodynamic properties derive primarily from weathering processes (Wyns et al., 1999; Taylor and Howard, 2000; Dewandel et al., 2006), where hostrock minerals are transformed into mainly clay-rich materials at surface equilibrium (Tardy, 1971; Nahon, 1991). From the top downward, hard-rock aquifers consist of two main layers: saprolite or regolith - a clay-rich material derived from prolonged in-situ weathering of the hostrockand a fissured layer characterized by dense sub-horizontal and -vertical fracturing in the first metres, below which fissure density decreases with depth (e.g. Dewandel et al., 2006). Such fractures either pre-existed or were caused by the swelling of certain minerals (e.g. biotite in granite), resulting in a local volume increase that generates cracks and fracturing. The fresh basement below is only locally permeable, where tectonic joints and fractures are present.

In India, as in other rapidly developing countries, groundwater use for domestic, industrial and agricultural activities is growing fast. Groundwater now irrigates 27 million hectares of farmland in India, a larger area than that irrigated by surface water (21 million ha). This change in water use has been extremely rapid since the start of the 'Green Revolution' in the 1970s; the number of bore wells has also increased enormously in the past 40 years, from less than one million in 1960 to over 26 million in 2007. For that reason, groundwater 
resources are under great stress, especially in hard-rock and (semi)arid areas, due to the abstraction of large quantities of water through pumping for irrigation that undermines the sustainability of water availability and agricultural development. Over the last decade, much of India, and particularly Andhra Pradesh, Karnataka, Maharasthra, Madhya Pradesh and Rajasthan, has suffered from drought, severe drops in groundwater level, and an alarming deterioration of water quality. It is thus imperative that groundwater resources be carefully managed and that institutions in charge of water management be equipped with suitable tools (Dewandel et al., 2007b).

Sustainable use of groundwater is quantitatively related to such factors as the volume of the existing resource, recharge, and associated environmental factors. From a groundwaterquality viewpoint, sustainability implies the prevention of deterioration of groundwater quality beyond acceptable and well-defined limits.

Stable isotopes of the water molecule have been investigated throughout India, as a support of fluoride-release investigations (Tirumalesh et al., 2007), as a tool for recharge and water-pathway characterization (Gupta et al., 2005; Sukhija et al., 2005; Mukherjee et al., 2007), for geothermal-water investigations (Majumdar et al., 2005), and for isotopic fingerprinting of paleo-climates in groundwater (Kulkarni et al., 1995; Sukhija et al., 1998). However, the trend of increasing groundwater exploitation has induced a major use of isotope tracing over the past three decades (Kumar et al., 1982; Gupta and Deshpande, 2005; Mukherjee et al., 2007; Négrel et al., 2007; Murad and Krishnamurthy, 2008). The main contribution of stable isotopes in fractured-rock hydrogeology concerns the identification of variably mixed groundwater reservoirs, of groundwater flow, and of resource renewal (Fontes, 1980, Praamsma et al., 2009).

The Maheshwaram watershed is representative of watersheds in southern India in terms of geology, overpumping of its hard-rock aquifer (more than 700 classical open-end 
wells in use), its cropping pattern (rice dominating), and its rural socio-economy mainly based on traditional agriculture (Dewandel et al., 2007a). Groundwater resources face chronic depletion, reflected in a strongly declining water table induced by a negative groundwater balance (Maréchal et al., 2006).

The aim of this work, based on a detailed study of the isotopic composition of groundwater and rainfall in the Maheshwaram watershed (Négrel et al., 2007), was to investigate the use of stable isotopes of the water molecule for tracing and fingerprinting the processes of groundwater-recharge (e.g. the monsoon input) and water-use in this typical rural Indian watershed experiencing agricultural water-resource overexploitation. As return flow was suspected to be an important process, a major goal of this investigation was to determine its potential impact on groundwater.

\section{General features of the catchment}

The $53 \mathrm{~km}^{2}$ Maheshwaram watershed (Fig. 1) is located $35 \mathrm{~km}$ south of Hyderabad (Ranga Reddy District, State of Andhra Pradesh). The area has a relatively flat topography with elevations between 590 and $670 \mathrm{~m}$ above sea level and no perennial streams (Kumar and Ahmed, 2003).

The semi-arid climate is controlled by the periodicity of the monsoon (rainy season: June-October). Mean annual precipitation is around $750 \mathrm{~mm}$, more than $90 \%$ of which falls during the monsoon season. The mean annual temperature is about $26^{\circ} \mathrm{C}$, but during summer, from March to May, maximum temperatures can reach $45^{\circ} \mathrm{C}$. The ratio of potential evaporation from soil plus transpiration by plants $(1800 \mathrm{~mm} / \mathrm{year})$ against the total quantity of rainwater, yields an aridity index of 0.42, typical of semi-arid areas (Maréchal et al., 2006). Surface streams are dry most of the year, except for a few days after very heavy rainfall during the monsoon. 

mainly orthogneissic granite with porphyritic K-feldspar. Intrusive leucocratic granite with a lower biotite content forms small hills and boulder-strewn outcrops. The weathering profile of these granites generally shows a thin layer of red soil $(10-40 \mathrm{~cm})$, a 1 to $3 \mathrm{~m}$ thick layer of sandy regolith, a 10 to $15 \mathrm{~m}$ thick layer of laminated saprolite, fractured granite that occupies the next 15 to $20 \mathrm{~m}$ and, farther down, fresh granite.

The groundwater budget of the depleted unconfined aquifer in the watershed can be summarized as follows. Horizontal groundwater inflow and outflow of the aquifer are very low compared to other terms (about $1 \mathrm{~mm} / \mathrm{year}$ ) and their difference is close to nil (Maréchal et al., 2006), baseflow representing groundwater discharge to streams or springs being nil (Kumar and Ahmed, 2003; Maréchal et al., 2006). Groundwater recharge is mainly direct as no permanent or temporary streams exist and only two tanks can serve as a source of indirect recharge (Dewandel et al., 2007b). The irrigation-return flow, according to Dewandel et al. (2007a), is variable in the area as a function of land-use (higher in rice paddies than in flower or vegetable plots) and evaporation from the water table is quasi nil (Maréchal et al., 2006). The water table for June 2002 (Maréchal et al., 2006) roughly follows the topographic slope, as is common in flat hard-rock areas. Water-table levels fluctuate between 610 and 619 masl, compared to a flat topography with elevations of 670 to $690 \mathrm{~m}$. The water table is thus everywhere in the fissured aquifer layer, but local cones of depression occur in areas where groundwater abstraction is high due to strong pumping for irrigation.

\section{Sampling procedures and analytical methods}

About 700 open-end wells fitted with submersible pumps, with depths ranging from 30 to $60 \mathrm{~m}$, are used for irrigation in the Maheshwaram watershed (Maréchal et al., 2006). The water samples were collected from these operational agricultural wells. Water temperature, 
electrical conductivity (EC) and $\mathrm{pH}$ of each sample were measured in situ, EC with a conductivity meter standardized to $20^{\circ} \mathrm{C}$ and $\mathrm{pH}$ using a $\mathrm{pH}$ electrode previously calibrated with standard buffers. Samples for stable-isotope determinations were stored in $50 \mathrm{ml}$ highdensity polyethylene bottles with small necks and caps sealed with paraffin film. The stable isotopes ${ }^{2} \mathrm{H}$ and ${ }^{18} \mathrm{O}$ were measured using a Finnigan MAT 252 mass spectrometer with a precision of $0.1 \%$ vs. SMOW (Standard Mean Ocean Water) for $\delta^{18} \mathrm{O}$ and of $0.8 \%$ for $\delta^{2} \mathrm{H}$. Isotopic compositions are plotted in the usual $\delta$-scale in \%o with reference to V-SMOW (Vienna Standard Mean Ocean Water) according to $\delta_{\text {sample }}(\%)=\left\{\left(\mathrm{R}_{\text {sample }} / \mathrm{R}_{\text {standard }}\right)-1\right\}^{*}$ 1000, where $\mathrm{R}$ is the ${ }^{2} \mathrm{H} /{ }^{1} \mathrm{H}$ or ${ }^{18} \mathrm{O} /{ }^{16} \mathrm{O}$ atomic ratio. Chloride analyses were performed by ion chromatography (uncertainty of $10 \%$ with a coverage factor $\mathrm{k}=2$ ), after filtration through $0.45 \mathrm{~mm}$ acetate filters (Pauwels et al., 2007).

In January 2006, after the rainy period, we selected a network of 24 open-end wells from the over 700 existing ones in the watershed for the groundwater collection to be representative of watershed recharge. In March 2006, the same network of open-end wells was sampled plus two others. One of the rare surface waters, a tank fed by the monsoon rains and afterwards only affected by evaporation, was also sampled several times to be representative of evaporation. Further sampling concerned 23 of the open-end wells from the network in July 2006, 11 open-end wells in November 2006, and 9 open-end wells in June 2008 and February 2009. During the different collection surveys, groundwater temperatures were 25.9 to $30.1{ }^{\circ} \mathrm{C}$.

In addition to the groundwater surveys, monsoon rainfall was collected for isotope characterization of the rainwater input into the watershed. To this end, rainfall gauge RF (Fig. 1) was designed and installed in the meteorological station of Maheshwaram village. As the samples were collected on a monthly basis, the isotopic composition of the sample was likely to be modified by evaporation. This was minimized by a special construction of the rain 
gauge, which included a 1.2-m-deep concrete excavation with a water depth of around $30 \mathrm{~cm}$, in which a cool box was placed. A 15 -cm-diameter tube connected the 5 -litre collection bottle to the rain-gauge funnel. A lid for lowering the evaporation and preserving the collecting system from direct input of the monsoon sealed the excavation.

During this study, we tried to reproduce the effect of evaporation on the basis of pan evaporation (Jhajharia et al., 2009). Evaporated water samples were taken from a galvanized evaporation pan installed far from vegetation and about $10 \mathrm{~cm}$ above the ground. The operating water level in the pan at the start of the experiment was $270 \mathrm{~mm}$ and the volume was $109.9 \mathrm{~L}$ from the rim. The experiment covered 55 days between November 2 and December 27, 2007, and concerned the analysis of $\mathrm{Cl}^{-}$contents and the stable isotopes $\delta^{2} \mathrm{H}$ and $\delta^{18} \mathrm{O}$, as described by Kattan (2008) from Syria.

\section{Results}

\section{1. $\delta^{2} \mathrm{H}$ AND $\delta^{18} \mathrm{O}$ ISOTOPIC SIGNATURES OF THE MONSOON}

The collection station in Maheshwaram village was operational from June to November 2006 and six monthly samples were collected. The results are given in Table 1. The amount of water ranged from $0.25 \mathrm{~L}$ in November to $4 \mathrm{~L}$ in September 2006. In all, $11 \mathrm{~L}$ of rainwater were collected for $10.5 \mathrm{~L}$ recorded by the meteorological station. Moreover, the linear relationship $(\mathrm{R}$ squared $=0.996)$ observed for the individual points (Iso_Rainfall gauge $=1.05$ x Meteo_Rainfall gauge $+0.02 ; \mathrm{n}=7$ ) confirms that all the monsoon rainfall was collected for the isotope survey (Table 1). The 2006 monsoon gave $517 \mathrm{~mm}$ of precipitation input on the watershed, which is considered as a low monsoon. The isotopes in the precipitation varied between $-1.2 \%$ in June and $-6.9 \%$ in October for $\delta^{18} \mathrm{O}$, and between $0.2 \%$ and $-44.4 \%$ for $\delta^{2} \mathrm{H}$. The mean weighted isotope compositions for the precipitation are $-3.83 \%$ and $-21.69 \%$ for $\delta^{18} \mathrm{O}$ and $\delta^{2} \mathrm{H}$, respectively (Table 1). These values are less depleted than those recorded at 
the nearby Hyderabad station with a mean weighted $\delta^{18} \mathrm{O}$ between April and November 1998 of $-6.5 \%$ (Sukhija et al., 2006), or than those from the Lower Maner Basin (Andhra Pradesh, north of Maheshwaram) where monthly composite precipitation samples in 1977 gave ranges of -4.1 up to $-5.1 \%$ for $\delta^{18} \mathrm{O}$ and of -25.7 up to -33.4 for $\delta^{2} \mathrm{H}$ (Kumar et al., 1982).

During the main rainy season (June to September), the west coast of India receives influx from the Arabian Sea as the monsoon blows in from the southwest and is uplifted by the Western Ghats. This section of the southwest monsoon is called the "Arabian Sea branch" (hereafter referred to as SW monsoon), generally with a low depletion of heavy isotopes (Deshpande et al., 2003; Gupta et al., 2005). In the Bay of Bengal, the monsoon current then takes a south-easterly turn, entering the Indo-Gangetic plains after being replenished with moisture from the Bay of Bengal. This section of the Indian monsoon is called the "Bay of Bengal branch" (hereafter referred to as NE monsoon) generally yielding a much larger depletion of heavy isotopes (Deshpande et al., 2003; Gupta et al., 2005).

In Maheshwaram, almost $70 \%$ of the rainfall is contributed by the $\mathrm{SW}$ monsoon from June to September and the rest by the NE monsoon from October to November (Kumar and Ahmed, 2003). During the 2006 monsoon this was quite different, with $54 \%$ of the rain falling from June to August and $46 \%$ from September to November. This indicates a change in the distribution between the two monsoons, as has been observed regularly since the 1990s with mean values of $59 \%$ and $41 \%$, respectively, for the SW and NE monsoons (data are from the meteorological station in Maheswharam). During the collection period, the $\delta^{18} \mathrm{O}$ and $\delta^{2} \mathrm{H}$ fell in two groups as illustrated on Figure 2. The first group yielded slightly depleted values of 1.2 to $-2.6 \%\left(\delta^{18} \mathrm{O}\right)$ and 0.2 to $-11.4 \%\left(\delta^{2} \mathrm{H}\right)$ that represent the SW-monsoon input between June and August, while the second one, between September and November, yielded a much larger depletion of heavy isotopes with values of -5.5 to $-6.9 \%\left(\delta^{18} \mathrm{O}\right)$ and -34.4 to $-44.4 \%$ o $\left(\delta^{2} \mathrm{H}\right)$, a typical range for the NE monsoon. Considering the distribution of the two monsoons, 
the SW monsoon became less and less dominant and thus the mean value of the rainfall was less and less depleted for $\delta^{18} \mathrm{O}$ (around $-3.83 \%$ for this study), compared to the previously reported values of less than $-5 \%$ for $\delta^{18} \mathrm{O}$ (Kumar et al., 1982; Sukhija et al., 2006).

Overall, when compared to the values from the SW and NE monsoons, the mean weighted values are depleted for the NE monsoon $\left(-43.1\right.$ and $-6.43 \%$ for $\delta^{2} \mathrm{H}$ and $\delta^{18} \mathrm{O}$, respectively) while they are enriched for the SW one $\left(-3.5\right.$ and $-1.6 \%$ for $\delta^{2} \mathrm{H}$ and $\delta^{18} \mathrm{O}$, respectively), which agrees with previous studies (Deshpande et al., 2003; Gupta et al., 2005). The NE monsoon was found to have values of around -60.7 and $-8.8 \%$ for $\delta^{2} \mathrm{H}$ and $\delta^{18} \mathrm{O}$, while the SW monsoon gave -17.1 and $-3.0 \%$ for $\delta^{2} \mathrm{H}$ and $\delta^{18} \mathrm{O}$.

We reproduced the monsoon collection in 2008 from June to November with a further six monthly samples. Similar to the 2006 monsoon, 12 L of rainwater was collected giving $620 \mathrm{~mm}$ of precipitation input on the Maheshwaram watershed. The isotopes in the 2008 precipitation varied in the same range as those of the 2006 monsoon (Table 1), with $\delta^{18} \mathrm{O}$ ranging from $0.1 \%$ o to $-7.4 \%$ and $\delta^{2} \mathrm{H}$ from $5.6 \%$ to $-49.7 \%$. The mean weighted isotope compositions for the precipitation are $-3.39 \%$ and $-17.05 \%$ for $\delta^{18} \mathrm{O}$ and $\delta^{2} \mathrm{H}$, respectively (Table 1). As illustrated on Figure 2, the two mean values are very close. As for the 2006 monsoon (Fig. 1), the two monsoon branches can be seen on Figure 2.

The rainwater-isotope data collected at the Maheshwaram station define a linear relationship $\delta^{2} \mathrm{H}=7.64 \pm 0.26 \times \delta^{18} \mathrm{O}+7.80 \pm 1.18\left(\mathrm{R}^{2}=0.989, \mathrm{n}=12\right)$. We used FREML (Functional Relationship Estimation by Maximum Likelihood, AMC, 2002) to give the best estimate of the slope and intercept of the co-variation. This local meteoric water line falls between the global meteoric water line $\delta^{2} \mathrm{H}=8 \delta^{18} \mathrm{O}+10$ of Craig (1961) and the linear relationship $\delta^{2} \mathrm{H}=7.6 \delta^{18} \mathrm{O}+6.3$ given by Kumar et al. (1982). The 1997 and 1998 monsoon data from the Global Network of Isotopes in Precipitation (IAEA/GNIP database on the web: 
http://isohis.iaea.org), the data of which define a linear relationship given as $\delta^{2} \mathrm{H}=6.91 \mathrm{x}$ $\delta^{18} \mathrm{O}+2.50\left(\mathrm{R}^{2}=0.989, \mathrm{n}=12\right)$, differ from those obtained during this study.

\section{2. $\delta^{2} \mathrm{H}$ AND $\delta^{18} \mathrm{O}$ ISOTOPIC SIGNATURES OF GROUNDWATER}

Results of isotopic analyses for the groundwater collected at different periods are given in Table 2. The isotope composition in the open-end well network shows a wide range in isotope compositions from -0.6 to $-4.1 \%$ for $\delta^{18} \mathrm{O}$ and from -6.6 to $-33.1 \%$ for $\delta^{2} \mathrm{H}$.

The main causes of variations in the stable-isotope signature of groundwater are natural variations in the isotopic composition of rainfall, mixing with pre-existing waters, and evaporation during percolation through soil and/or the unsaturated zone (Kendall and McDonnell, 1998). In view of the temperatures generally encountered in the subsurface, the stable isotopes of water can be considered as conservative and not affected by exchanges with soil or rock (Barth, 2000).

The $\delta^{2} \mathrm{H}$ and $\delta^{18} \mathrm{O}$ values of the groundwater samples collected in January are plotted on Figure 2 with the local meteoric water line and its 95\% uncertainty envelopes (LMWL), and the global meteoric water line (GMWL, Craig, 1961); those earlier defined by Kumar et al. (1982) plot in the 95\% LMWL uncertainty envelopes and are not shown on the figure. Figure 2 shows only the data obtained in January, which represent recharge that mixed with pre-existing water. Figure 2 also shows all sampling periods (January plus March, July and November 2006, June 2008 and February 2009). Groundwater in the watershed collected in January 2006 defines a co-variation with a statistically significant correlation when tested with Pearson's parametric or Spearman's nonparametric tests for correlation with values of 0.985 (at $\alpha=0.05$ ). Using FREML, the equation is $\delta^{2} \mathrm{H}=6.17 \pm 0.25 \times \delta^{18} \mathrm{O}-0.54 \pm 0.67(\mathrm{n}=$ 24). Groundwater also defines a co-variation in March, June, November 2006, June 2008 and February 2009 with Pearson and Spearman's R coefficients higher than 0.98. The equations 
are given in Table 3 for all periods and few differences can be observed considering the $95 \%$ uncertainty envelopes.

\subsection{IMPACT OF EVAPORATION ON $\delta^{2} \mathrm{H}$ AND $\delta^{18} \mathrm{O}$ ISOTOPIC SIGNATURES} The $\delta^{2} \mathrm{H}-\delta^{18} \mathrm{O}$ relationship due to evaporation of water can be predicted on the basis of a steady-state isotope-balance model using temperature, humidity, isotopes in precipitation and a liquid-vapour equilibrium model. This is based on the Craig-Gordon model (see review in Gat, 2008). A slope of around 4 in a $\delta^{2} \mathrm{H}-\delta^{18} \mathrm{O}$ relationship is generally observed either in surface water during dry-season flow (Négrel and Lachassagne, 2000; Gibson et al., 2008), or in the prediction of the Craig-Gordon model for an open-water dominated evaporative system. Allison et al. (1984) showed a slope of between 4 and 6 in a $\delta^{2} H-\delta^{18} \mathrm{O}$ relationship for the residual liquid when water evaporates from lakes and rivers or saturated soil, and of between 2 and 5 when evaporation affects an unsaturated soil profile.

A pan evaporation experiment was carried out for 55 days between 2 November and 27 December 2007. Starting with a $\mathrm{Cl}^{-}$of $4.2 \mathrm{mg} \mathrm{L}^{-1}$, it reached $33 \mathrm{mg} \mathrm{L}^{-1}$ at the end of the experiment, leading to a concentration factor of 7.9. At the same time, the water volume decreased from 109.9 $\mathrm{L}$ at the start to reach $20.6 \mathrm{~L}$ at the end, i.e. a factor of 5.3. The $\delta^{2} \mathrm{H}$ and $\delta^{18} \mathrm{O}$ started with respective values of -15.11 and $-1.58 \%$ and reached respectively +65.06 and $+17.73 \% 55$ days later; this corresponds to the equation

$$
\delta^{2} \mathrm{H}=4.19 \pm 0.09 \times \delta^{18} \mathrm{O}-9.17 \pm 0.98 \text { (using FREML, } \mathrm{R}^{2}=0.998, \mathrm{n}=5 \text { ) }
$$

reflecting an evaporation relationship with a slope of $4.19 \pm 0.09$ (Fig. 3a). This value fully agrees with the evaporation slopes of about 4.7 given by Navada et al. (1999) for Rajasthan and of around 4.9 found by Kulkarni et al. (1995) in the central Indo-Gangetic plain.

One of the rare surface waters, a tank in the centre of the watershed, was sampled in March and September 2006 and in February 2009 to be representative of evaporation, as the 
tank was fed by monsoon rain and afterwards was only affected by evaporation. The $\delta^{2} \mathrm{H}$ and $\delta^{18} \mathrm{O}$ values of the tank water plot along the line defined by the pan-evaporation experiment, corroborating the effect of evaporation on this surface water (Fig. 3a).

Deuterium excess ('D-excess') in groundwater samples is expressed as $\delta \mathrm{D}-8 \delta^{18} \mathrm{O}$. The 'D-excess' values are $<10$, ranging from 1.1 to 7.5 in January, from -0.6 to 7.6 in March, from -9 to 7.5 in June, from -5.7 to 7.3 in November 2006, and from -4.5 to 7.2 in June 2008 . The tank sample shows a 'D-excess' of -7.9 in March, -2.2 in November and -28.2 in February 2009. The lowest 'D-excess' values in the open-end wells are always observed for the M35 (around -9). The 'D-excess' values are plotted versus $\delta^{18} \mathrm{O}$ on Figure 4.

The water loss through evaporation in semi-arid zones is illustrated on Figure $3 \mathrm{~b}$ where $\delta^{18} \mathrm{O}$ values for the pan experiment and the tank are plotted versus $\mathrm{Cl}$ contents. Starting from the mean monsoon (2006 and 2008), dissolved salts in the evaporation experiment concentrate by evaporation steps and the $\delta^{18} \mathrm{O}-\delta^{2} \mathrm{H}$ values have a slope reflecting kinetic fractionation; the $\mathrm{Cl}^{-}-\delta^{18} \mathrm{O}$ relationship should thus be positively correlated as any increase in evaporation would result in isotopic enrichment as well as in a higher $\mathrm{Cl}$ content. The $\mathrm{Cl}-$ $\delta^{18} \mathrm{O}$ relationship defines a steep slope as less isotope variations would occur with increasing salinity (Fig. 3b). Compared to this natural evolution, the tank also integrates the input of $\mathrm{Cl}$ through human and agricultural activities, causing an increase in $\mathrm{Cl}$ content that can be quite large, as shown by the February 2006 sample.

\section{Discussion}

\subsection{DISTRIBUTION OF RECHARGE IN SPACE}

The $\delta^{2} \mathrm{H}$ and $\delta^{18} \mathrm{O}$ values of the groundwater samples collected in January 2006 lie closely around the local meteoric water line (LMWL, Fig. 2), confirming that the groundwater most 
probably comes from present-day precipitation, though with a significant shift to the right of the LMWL. This reflects only evaporation during the percolation through soil and saprolite, as evaporation from the water table is nil (Maréchal et al., 2006) although an enrichment in heavy isotopes by irrigation-return flow is possible as well. Percolation through soil and saprolite may generate the shift to the right of the LMWL; Lee et al. (2007) showed that soil waters in a $\delta^{18} \mathrm{O}-\delta^{2} \mathrm{H}$ space plot close to the local meteoric water lines, indicating recharge from year-round precipitation and negligible evaporation, even during the hot summer season. Mathieu and Bariac (1996), studying groundwater recharge, found fast and direct infiltration through conducting fissured zones, generating $\delta^{18} \mathrm{O}$ values at a depth of a few metres that were close to the mean rainfall input, while slow infiltration through soil and the upper $0.5 \mathrm{~m}$ of weathered basement rock generated enriched $\delta^{18}$ O values. Sami (1992), in South Africa, also found some evaporative enrichment in groundwater during recharge, as did Navada et al. (1999) and Nair et al. (2001) in Rajasthan who showed a similar $\delta^{2} \mathrm{H}-\delta^{18} \mathrm{O}$ relationship in groundwater as we did, and also found similar $\delta^{18} \mathrm{O}$ values at depth $(>10 \mathrm{~m})$ as well as enriched values in the first metre of soil and saprolite.

The $\delta^{2} \mathrm{H}-\delta^{18} \mathrm{O}$ relationship (Fig. 2) intercepts the LMWL around $\delta^{18} \mathrm{O}=-5.5 \%$, suggesting this value to be the approximate $\delta^{18} \mathrm{O}$ composition of rainwater. However, this value of $-5.5 \%$ disagrees with the weighted mean monsoon value of -3.39 to $-3.83 \%$ o determined in this study, and also disagrees with that of Kumar et al. (1982) who gave a $\delta^{18} \mathrm{O}$ ranging from -4.1 to $-5.1 \%$. Moreover, the distribution of groundwater values on Figure 2 shows some points that plot around the LMWL close to the mean monsoon value. Evaporation of representative water of the mean monsoon value alone cannot be the process that causes a shift from the LMWL, considering the mean $\delta^{18} \mathrm{O}$ composition of the monsoon $(-3.39$ to $-3.83 \%)$ and the pan-evaporation experiment that led to a slope of $4.19 \pm 0.09$, quite different from the groundwater one $(6.17 \pm 0.25)$. This suggests different stages of groundwater 
recharge with isotope signatures in close connection with those of the dual monsoon as shown also by Deshpande et al. (2003) for shallow groundwater in southern India. Thus, the first step is related to input from the $\mathrm{SW}$ monsoon, resulting in slightly depleted $\delta^{18} \mathrm{O}$ values, while the second one is related to input from the NE monsoon yielding much more depleted $\delta^{18} \mathrm{O}$ values. The linear relationship defined in the groundwater thus reflects the mixing between the two rainfall inputs, explaining the data distribution along the $\delta^{18} \mathrm{O}$ line ranging from $-5 \%$ to $-0.5 \%$. Some groundwater clearly reflects a recharge due to the $\mathrm{SW}$ monsoon without any significant influence of the NE one, which may reflect a saturated soil that limited rainwater percolation during the second monsoon stage. On the contrary, the few points that are more depleted when compared to mean monsoon values are more influenced by the NE monsoon.

The $6.17 \pm 0.25$ slope of the linear relationship between all points in the $\delta^{2} \mathrm{H}-\delta^{18} \mathrm{O}$ plot, differs from that of LMWL $(7.64 \pm 0.26)$ and is caused by a larger influence of evaporation affecting groundwater recharge during the SW monsoon. The water loss through evaporation in semi-arid areas assumes importance as the heavy-isotope content of groundwater becomes enriched relative to that of precipitation (Fontes, 1980; Navada et al., 1999; Nair et al., 2001; Kattan, 2008). This suggests that the transfer velocity from rainfall towards groundwater storage through soil and the unsaturated zone is sufficiently low, and that post-precipitation evaporation during the passage in soil and the unsaturated zone is an active process, having a greater impact for the second part of the monsoon period than for the first part, as also suggested by Navada et al. (1999) in Rajasthan, Majumdar et al. (2005) in eastern India, and Gupta et al. (2005) in central India. However, this is contrary to the observations by Stüber et al. (2003) in West Bengal and by Négrel et al. (2007) on the Subarnarekha River system (Jharkhand State).

This is further shown by the plot of 'D-excess' vs. $\delta^{18} \mathrm{O}$ (Fig. 4). The 'D-excess' values in groundwater samples are less than 10 (range -0.6 to 7.6 ) and fluctuate together with 
the $\delta^{18} \mathrm{O}$ (Pearson and Spearman's R coefficients of around -0.85). Therefore, 'D-excess' values of around 8 in groundwater may be inherited from precipitation during the monsoon as their similarity with the $\delta^{18} \mathrm{O}$ monsoon values confirms minor evaporation (Deshpande et al., 2003; Gupta et al., 2005). 'D-excess' values of less than 5, however, suggest significant evaporation of rainwater, leaving the residual groundwater with lower 'D-excess' values and depleted $\delta^{18} \mathrm{O}$. The water in the tank plots along the same relationship, with 'D-excess' values close to the lowermost ones observed in groundwater (Fig. 4). This confirms that evaporation has a similar impact on ground- and surface waters.

\subsection{EVOLUTION OVER TIME OF STABLE ISOTOPES IN GROUNDWATER}

\subsubsection{Water dynamics at the watershed scale}

Groundwater in the watershed is defined by co-variations in March, June, November 2006, June 2008, and February 2009 (Pearson and Spearman's R coefficients $>0.98$, Fig. 2). The covariation slope in March $(6.44 \pm 0.18$, Table 3$)$ fully agrees with that observed in January (6.17 \pm 0.25$)$, and a set of slopes lower than 6 (Table 3$)$ is observed for June $2006(5.30 \pm 0.19)$,

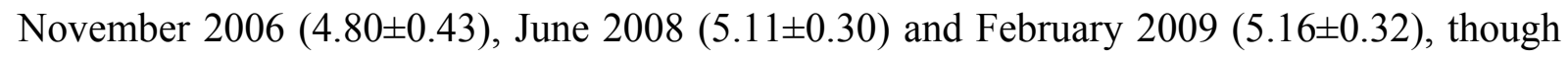

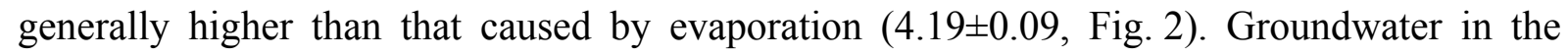
watershed is extensively used for irrigation, which implies irrigation-return flow (Dewandel et al., 2007a) that may be affected by evaporation. Intensive pumping may result in mixing between enriched irrigation-return-flow water and more depleted groundwater (Basu et al., 2002; Zheng et al., 2005).

The rural socio-economy in the Maheshwaram watershed is based on traditional agriculture, the main crop being rice that requires much irrigation water. In semi-arid climates (Simpson et al., 1992), a major part of the water used for rice production returns to the atmosphere through the combined effects of evaporation and transpiration. Both processes cause enrichment of the residual water in heavier isotopes, evaporation leading to stronger 
enrichment than transpiration (Clark and Fritz, 1997). Simpson et al. (1992), studying the flooding of rice paddies in Australia, found a slope of the $\delta^{2} \mathrm{H}-\delta^{18} \mathrm{O}$ relationship for the return-flow water similar to that observed in evaporation pans in the same region. Therefore, evaporation would cause a shift for the slope of the $\delta^{2} \mathrm{H}-\delta^{18} \mathrm{O}$ co-variation in groundwater towards the lower value by the end of the irrigation period in June and May, which would remain low up to the end of the recharge period (after the end of the monsoon in November, plus the transfer through the unsaturated zone). Maréchal et al. (2006) calculated that around $40 \%$ of the pumped water returns to the aquifer, and Dewandel et al. (2007a) showed the irrigation-return-flow coefficients (ratio between pumping abstraction versus return flow) to be $10 \%$ for flowers, $25 \%$ for vegetables and around $50 \%$ for rice. This means that the effect of the return flow on the $\delta^{2} \mathrm{H}-\delta^{18} \mathrm{O}$ signature of groundwater is variable as a function of land use. Taken as a whole over the watershed, the observed small effect on $\delta^{2} \mathrm{H}$ and $\delta^{18} \mathrm{O}$ in groundwater, which show about the same values as those observed in January during the collection period (Table 3), suggests that the return-flow process has a relatively minor impact on the $\delta^{2} \mathrm{H}-\delta^{18} \mathrm{O}$ signature of groundwater even if it is important (around $80 \%$ of the aquifer volume on a yearly basis, Dewandel et al., 2006). This will be further discussed hereafter when comparing the data at the open-end well scale, as a working hypothesis could be the scale effect because land-use patterns differ in the watershed (de Condappa, 2005), with paddy fields dominating in some parts compared to grape and fruit growing in others.

\subsubsection{Downscaling water dynamics: land-use effect at the bore-well scale}

There is some variation in the stable-isotope composition between sites, suggesting a heterogeneous origin of the water in the aquifer; this first heterogeneity is related to the variation in recharge as demonstrated before. Investigation of the water dynamics should consider specific use of a well, for which several features can be stated. First, there is a 
variation or lack of variation in site(s) that may reflect different processes. Hereafter, we consider the case of open-end wells located in parts of the watershed with different water use. First we will investigate the effect of moderate use of groundwater for cultivation from three open-end wells. The first is the little-used open-end well M57 that supplies a dress factory, the two others are open-end wells M12 and M14, respectively used for drip irrigation of grape vines and mango trees. After that, we consider the larger use of groundwater from open-end wells M30, 35, 50 and 53, used for rice growing and vegetable- and flower cultivation. Records for January, March, June and November 2006 were collected for open-end wells M12, 14 and 57 (Fig. 5) plus June 2008 and February 2009 for M12 and M57. For open-end well M14 there is no variation between the periods, and the data plot close to the meteoric water lines and the mean weighted monsoon value of 2006. This suggests that recharge is rapid and concerns the two monsoon periods, as the January values for $\delta^{18} \mathrm{O}$ and $\delta^{2} \mathrm{H}$ reflecting recharge (Fig. 2) fall on the meteoric water lines. The groundwater is not affected by evaporation and the $\delta^{18} \mathrm{O}$ and $\delta^{2} \mathrm{H}$ values of the groundwater mimic those of the mean weighted monsoon, suggesting that recharge occurs during the monsoon period from June to December, with physical parameters of soil and saprolite that allow fast and direct recharge (Mathieu and Bariac, 1996). It is obvious that evaporation, either from percolation through soil and saprolite, or directly from the water table, is nil (Maréchal et al., 2006) as the $\delta^{2} \mathrm{H}-\delta^{18} \mathrm{O}$ values in the aquifer agree with the meteoric water input. Following the recharge period, the other surveys show similar $\delta^{18} \mathrm{O}$ and $\delta^{2} \mathrm{H}$ values, suggesting that the water body supplying the water in open-end well M14 is the same throughout the period, leading to the conclusion that no return flow occurs during drip irrigation of mango trees.

Open-end well M57 functioned similarly to open-end well M12 for the first five periods, without variation in the $\delta^{2} \mathrm{H}-\delta^{18} \mathrm{O}$ values between the first four periods whose data plot close to the meteoric water lines and the mean weighted monsoon value of 2006. This 
agrees with recharge during the June to December monsoon period, with soil and saprolite characteristics that allow fast and direct recharge to be dominant. The groundwater around open-end well M57 supplies a dress factory and a recent increase in the pumping frequency has shown a shift of the last collected sample (February 2009) along the evaporation line. The response of the aquifer to this change in water abstraction is relatively rapid as the time interval is around 8 months (between June 2008 and February 2009).

Open-end well M12 functions differently. Even though the three periods of January, March and June 2006 had similar $\delta^{18} \mathrm{O}$ and $\delta^{2} \mathrm{H}$ values, they all plot along the evaporation line. For November 2006, after the recharge period, the groundwater values are close to those of the mean monsoon, again suggesting rapid recharge (Mathieu and Bariac, 1996) without any impact from evaporation. In June 2008, the value was close to that of November 2006, but plotted differently to those observed in June 2006 and February 2009, plotting close to November 2006 and June 2008 values but different from the March 2006 one. This suggests that recharge was sufficiently minor to balance the enriched $\delta^{18} \mathrm{O}$ and $\delta^{2} \mathrm{H}$ values observed between January and June 2006, but was strong enough to affect the groundwater $\delta^{18} \mathrm{O}$ and $\delta^{2} \mathrm{H}$ values between November and February 2009. But, as the $\delta^{18} \mathrm{O}$ and $\delta^{2} \mathrm{H}$ values in groundwater differ from the meteoric water lines through evaporation during the period between January and June 2006, this may indicate that the water body from which the water is pumped was affected by returned irrigation flow. On the other hand, the water body seems to be less affected by evaporation during the period from November 2008 to February 2009, suggesting less water use in this area where grape vines are drip irrigated. A rice paddy is located close to the open-end well, affecting the groundwater body during the rice-growing season (not all the time) through a partly identified return irrigation flow.

We now consider open-end wells M30, 35, 50 and 53, used for rice growing and vegetable- and flower cultivation. Data for all five periods were collected for open-end wells 
M50, 53 and 30, and for four periods for open-end well M35 (Fig. 5, cont'd). All wells are located near paddy fields and used throughout the irrigation period for flooding the paddies twice a day, all points evolving along the evaporation line. This agrees with groundwater pumping during the irrigation period from the same water body, any compositional change being only controlled by returned irrigation flow. The January values for the open-end wells reveal that all were affected by evaporation as the values depart from the meteoric water lines, but all are also different from the mean weighted 2006 monsoon value, suggesting once again that fast and direct recharge is dominant. Moreover, they evolve similarly during the irrigation period. The groundwater from well M53 falls on the evaporation line, with the March and June 2006 points being close to that of the January recharge, indicating abstraction from the same water body during the irrigation period. The points collected in November 2006 and February 2009 show a slightly more evaporated signature, probably reflecting a returned irrigation flow rather than a change in the water origin, which was also observed in June 2008. The groundwater from well M50 evolved similarly from recharge in January plotting along the evaporation line up to March, and June samples that migrated along the evaporation line. One key observation concerns the location along the evaporation line of the February 2009 samples that plot with the most strongly shifted values, indicating that either the return flow was large at that time, or that the monsoon recharge was not yet visible in the $\delta^{18} \mathrm{O}$ and $\delta^{2} \mathrm{H}$ signatures of the groundwater. For well M35 the January and March samples do not differ in signature, but evaporation strongly affected the June ones resulting in a heavyisotope enrichment of the water. Such evidence of evaporation is not linked to processes affecting the water table and the only way to explain such evaporation is by large returned irrigation flow after enrichment of the water through evaporation in the paddy fields and transpiration from the rice (Simpson et al., 1992). The June samples for both 2006 and 2008 thus represent a clear mixture of the groundwater that was used for irrigation between January 
and March with the strongly evaporated returned irrigation flow. The November sample lies on the same evaporation line as the other samples of the same well, but with $\delta^{18} \mathrm{O}$ and $\delta^{2} \mathrm{H}$ values between those of June and March, showing a shift back to the monsoon value along the LMWL corresponding to the end of the 2007 monsoon. This implies that the groundwater collected in November was partly controlled by the signature of the (mostly evaporated) return flow and by the recharge signature of the SW Monsoon. For February 2009, similar to well $\mathrm{M} 50, \delta^{18} \mathrm{O}$ and $\delta^{2} \mathrm{H}$ plot with the most shifted values, again indicating that the groundwater is largely controlled by the signature of the evaporated return flow. Considering that the February sample still includes part of the 2008 monsoon, the $\delta^{18} \mathrm{O}$ and $\delta^{2} \mathrm{H}$ values indicate a shift back to the monsoon value and thus that the maximum of the $\delta^{18} \mathrm{O}$ and $\delta^{2} \mathrm{H}$ signatures of the groundwater affected by return flow may be higher.

In case of such binary mixing, the following equation applies:

$$
\mathrm{M}=\mathrm{a} \mathrm{EM}_{1}+(1-\mathrm{a}) \mathrm{EM}_{2}
$$

where $\mathrm{M}$ corresponds to the mixture, $\mathrm{EM}_{1}$ and $\mathrm{EM}_{2}$ to the two end-members, and a being the mixing parameter, i.e. the proportion of EM1 and EM2 in the mixing. This gives for a

$$
\mathrm{a}=\left(\mathrm{M}-\mathrm{EM}_{2}\right) /\left(\mathrm{EM}_{1}-\mathrm{EM}_{2}\right)
$$

Considering the November sample as the mixture in M50, the June samples as $\mathrm{EM}_{1}$ and the January one as $\mathrm{EM}_{2}$, mixing parameter a can be calculated by using equation 2 . The result shows that around $70 \% \pm 0.5$ (propagated error according to classical formulae of equations 2 derivatives) of the water in the November sample comes from $\mathrm{EM}_{1}$ (June samples) and around $30 \% \pm 0.1$ (propagated error) from $\mathrm{EM}_{2}$ (January recharge). Parameter a suggests that most of the recharge through soil and the unsaturated zone occurs between November and January. For the M35 case, we can also consider the November sample as the mixture and the January sample as the recharge $\left(\mathrm{EM}_{2}\right)$, defining the returned flow as the most shifted value with $\delta^{18} \mathrm{O}$ around $0.5 \%$. Using equation 2, mixing parameter a gives around 
$50 \%$ for each end-member, showing that groundwater like that of November can be affected for around $65 \% \pm 3$ (propagated error) by return flow, agreeing with the estimate given by Dewandel et al. (2007a) for the irrigation return-flow coefficients of around 50\% for rice.

Open-end well M30 is characterized by a more marked NE-monsoon recharge with values close to the mean weighted monsoon value. It experienced evaporation as the recharge values (January sample) depart from the meteoric water lines and the March and June 2006 samples plot along an evaporation line, both values being similar but with a more marked evaporation signal compared to the January sample. The June and November 2008 and February $2009 \delta^{2} \mathrm{H}$ and $\delta^{18} \mathrm{O}$ values are increasingly marked by the evaporation signal, though with a less evaporated signal than that found in well M35. The influence of returned flow is strongly suggested. Considering the November sample as the mixture, the February samples as $\mathrm{EM}_{1}$ and the January one as $\mathrm{EM}_{2}$, mixing parameter a can be calculated with equation 2 showing that around $80 \% \pm 12$ (propagated error) of the water in the November sample comes from $\mathrm{EM}_{1}$ (February sample) and around $20 \% \pm 4$ (propagated error) from $\mathrm{EM}_{2}$ (January recharge). Here, parameter a suggests that groundwater like the November one can be affected around $80 \pm 12 \%$ by return flow, a higher value than the $50 \%$ estimate of Dewandel et al. (2007a) on the irrigation return-flow coefficients for rice.

The M35 and M30 calculations led to the conclusion that isotopes of the water molecule, at the bore-well scale, may help in quantifying the land-use effect, i.e. return flow.

\subsubsection{Effect of land use: impact on salinity and stable-isotope signature of the groundwater}

In order to evaluate the source of salt in groundwater at the watershed scale, chloride concentrations were plotted against the $\delta^{18} \mathrm{O}$ signature of the groundwater (Fig. 6). As the bedrock contains no evaporites, chloride concentrations in groundwater do not derive from weathering and must originate from both evaporation of rainwater and human activity 
(Négrel, 1999; 2006). Data were plotted with those from Sukhija et al. (2006), obtained in weathered/fractured granite near Hyderabad (India), $30 \mathrm{~km}$ north of Maheshwaram. The highest $\mathrm{Cl}^{-}$concentration in rainwater, $(\mathrm{Cl})_{\text {ref }}$, was determined according to the method defined by Négrel et al. (1993); it was calculated with the chloride content in rainwater, a mean weighted value of close to $1.9 \mathrm{mg} \mathrm{L}^{-1}$ during the monsoon, multiplied by the concentration factor F (Négrel, 1999). This factor F represents the concentration effect of evapotranspiration and is related to the total quantity of rainwater $\mathrm{P}$ (in $\mathrm{mm}$ ) and the evapotranspiration process $\mathrm{E}$ (in $\mathrm{mm}$ ) by the equation $\mathrm{F}=\mathrm{P} /(\mathrm{P}-\mathrm{E})$. According to the data given by Maréchal et al. (2006) for the watershed, F ranges between 4.5 and 11, leading to a maximum of rain-derived $\mathrm{Cl}$ of 8 to $20 \mathrm{mg} \mathrm{L}^{-1}$. The lowest chloride concentrations observed in Maheshwaram groundwater are $<5 \mathrm{mg} \mathrm{L}^{-1}$ (Pauwels et al., 2007) and thus only some samples can be considered as representative of the natural background by rain input without human influence. However, the samples with the highest chloride concentrations are also those with the highest nitrate concentrations, suggesting a common origin for these two elements (domestic sewage, in-situ sanitation, livestock farming, fertilizer spreading). Some groundwater with a $\delta^{18} \mathrm{O}$ signature similar to that of the mean monsoon rain input, i.e. around -3.5 to $-4 \%$, shows a large variation in $\mathrm{Cl}$ content (Fig. 6), from less than $\mathrm{Cl}_{\text {ref }}$ with a minimum of $2.6 \mathrm{mg} \mathrm{L}^{-1}$ up to $250 \mathrm{mg} \mathrm{L}^{-1}$, whereas with a more enriched $\delta^{18} \mathrm{O}$ signature of around $-3 \%$ the $\mathrm{Cl}$ content is $>400 \mathrm{mg} \mathrm{L}^{-1}$. This could be due to several steps of evaporation year after year. However, if mixing occurs, due to groundwater exploitation for example, a poor correlation might be observed (Kattan, 2008).

On Figure 6, according to the pan-evaporation experiment, the line where groundwater variations are due only to recharge (i.e. monsoon input, Fig. 3a, b) and evaporation (percolation through soil and saprolite), should show a weak impact on the $\delta^{18} \mathrm{O}$ and $\mathrm{Cl}^{-}$ contents, as it starts from the mean rain input but never reaches the maximum of rain-derived 
$\mathrm{Cl}^{-}$of up to $20 \mathrm{mg} \mathrm{L}^{-1}$. Thus, considering one-step evaporation processes, the $\mathrm{Cl}^{-}$content should only reach a low value, around $5 \mathrm{mg} . \mathrm{L}^{-1}$.

In order better to understand the joint evolution of $\mathrm{Cl}^{-}$and $\delta^{18} \mathrm{O}$, we created a daily mass-balance model covering the 20-year period of overpumping of the Maheshwaram watershed, which started close to the beginning of the Green Revolution. Overexploitation can be seen in the strongly declining water table caused by a negative groundwater balance (Maréchal et al., 2006). Starting with about 10 open-end wells in 1985, the watershed contained more than 150 open-end wells in 1995 and up to 700 in 2005 . For $\mathrm{Cl}$, rainfall is the only source to be considered in the model as man-induced $\mathrm{Cl}$ inputs do not influence the Oisotopes. Furthermore, no $\mathrm{Cl}$ sink is considered as overpumping of the groundwater leads to endorheic functioning of the watershed (Maréchal et al., 2006) and groundwater becomes increasingly salty though without reaching oversaturation with respect to Cl-solid phases (Pauwels et al., 2007). Soils in the watershed cannot act as $\mathrm{Cl}$ sinks as they are clayey/sandy without an organic layer (de Condappa, 2005).

The model considers a constant mean value for rainfall and an identical recharge every year. For rainfall values, we used the mean weighted value of $\mathrm{Cl}$ during the monsoon period (1.9 $\mathrm{mg} \mathrm{L}^{-1}$ ), and a mean weighted $\delta^{18} \mathrm{O}$ value was used for the June-August period and another for September-November, representing the dual monsoon (Deshpande et al., 2003).

The volumes of recharge, pumping and return flow for the simulation are from Dewandel et al. (2007). Even if the volume of water in the aquifer varies within a year, it returns to the same initial value by the end of every year. The initial condition was estimated and concerns the mean piezometric elevation of the water table $(617 \mathrm{~m}$ on average according our field data over 2002, 2003, 2004; see also Maréchal et al., 2006), the mean bedrock elevation (604 m), and a specific yield of 0.014 (Dewandel et al., 2006, 2007a). The aquifer volume can be calculated and thus for one aquifer volume the rainfall volume (recharge) is 
0.5 , the volume of the aquifer pumped is 0.96 and the return flow is 0.48 of the pumped volume. Recharge occurs in this model over 120 days. One should also consider the twice yearly rice harvest (Dewandel et al., 2007a). The first rainy season between June and October, Kharif, has an average duration of 137 days when watering is from rainfall and irrigation, the second period between November and April, Rabi, covering 166 days when watering is from irrigation only (Perrin et al., 2006). We also considered a watering period of one month before planting when the pumped volume is 0.1 the normal aquifer volume (Dewandel et al., 2007a).

The isotopic signature of the aquifer $\delta^{18} \mathrm{O}_{\mathrm{T}}$ can be calculated as follows:

$$
\delta^{18} \mathrm{O}_{\mathrm{T}}=\delta^{18} \mathrm{O}_{\mathrm{j}-1} \times \mathrm{V}_{\mathrm{j}-1} / \mathrm{V}_{\mathrm{T}}+\delta^{18} \mathrm{O}_{\mathrm{RF}} \times \mathrm{V}_{\mathrm{RF}} / \mathrm{V}_{\mathrm{T}}-\delta^{18} \mathrm{O}_{\mathrm{p}} \times \mathrm{V}_{\mathrm{p}} / \mathrm{V}_{\mathrm{T}}+\delta^{18} \mathrm{O}_{\mathrm{Rd}} \times \mathrm{V}_{\mathrm{Rd}} / \mathrm{V}_{\mathrm{T}} \text { (Eq. 3) }
$$
where:

- $\delta^{18} \mathrm{O}_{\mathrm{RF}}$ is the isotopic signature of the return flow corresponding to $\delta^{18} \mathrm{O}_{\mathrm{p}}+\mathrm{a}\left(\delta^{18} \mathrm{O}_{\mathrm{p}}\right.$ being the isotopic signature of the pumped water, and a the daily enrichment in heavy isotopes, assumed from an evaporation pan with a value of 0.35 );

- $\delta^{18} \mathrm{O}_{\mathrm{Rd}}$ is the isotopic signature of rainfall, for which two $\delta^{18} \mathrm{O}$ values were used $(-1.61 \%$ o for June-August and -6.43\%o for September-November);

- $\mathrm{V}_{\mathrm{RF}}$ is the volume of return flow, daily calculated with the equation $\mathrm{V}_{\mathrm{RF}}=0.48 \times \mathrm{V}_{\mathrm{P}}$;

- $\mathrm{V}_{\mathrm{P}}$ is the pumped volume, daily calculated according to $\mathrm{V}_{\mathrm{P}}=0.96 \times \mathrm{V}_{\mathrm{T}-1} /$ days of pumping (166 for the Kharif period and 137 for the Rabi period);

- $\mathrm{V}_{\mathrm{Rd}}$ is the volume of direct recharge, daily calculated according to $\mathrm{V}_{\mathrm{Rd}}=0.5 \times \mathrm{V}_{\mathrm{P}} / 120$;

- $\mathrm{V}_{\mathrm{T}}$ if the total volume according to $\mathrm{V}_{\mathrm{T}}=\mathrm{V}_{\mathrm{T}-1}+\mathrm{V}_{\mathrm{RF} 70}+\mathrm{V}_{\mathrm{Rd} 70}-\mathrm{V}_{\mathrm{P}}$ (the volume of return flow and direct recharge are considered over 70 days after the beginning of pumping and rainfall, and $\mathrm{V}_{\mathrm{T}-1}$ is the aquifer volume the day before).

A similar equation was used for simulating the Cl-content variations:

$$
\mathrm{Cl}_{\mathrm{T}}=\mathrm{Cl}_{\mathrm{j}-1} \times \mathrm{V}_{\mathrm{j}-1} / \mathrm{V}_{\mathrm{T}}+\mathrm{Cl}_{\mathrm{RF}} \times \mathrm{V}_{\mathrm{RF}} / \mathrm{V}_{\mathrm{T}}-\mathrm{Cl}_{\mathrm{p}} \times \mathrm{V}_{\mathrm{p}} / \mathrm{V}_{\mathrm{T}}+\mathrm{Cl}_{\mathrm{Rd}} \times \mathrm{V}_{\mathrm{Rd}} / \mathrm{V}_{\mathrm{T}}
$$


The results of the simulation are presented in Figure 7, the annual changes covering 10, 15 and 20 years. This allows evaluating both intra-annual and inter-annual variations. From these changes, we can state, first, that the chloride content in the groundwater increases as a time function over 10 to 20 years of aquifer exploitation, while, second, the $\delta^{18} \mathrm{O}$ signature does not follow the same evolution and stays within the same range of -3 to $-3.5 \%$ over 10 to 20 years of aquifer exploitation. Propagated errors on the $\delta^{18} \mathrm{O}$, according to classical formulae of equations 3 derivative agree with the stability of the signal as the values of the error never exceed $0.4 \%$. After 15 years of aquifer overpumping, the simulation results match some of the observed chloride contents (e.g. around $26 \mathrm{mg} \mathrm{L}^{-1}$ ) for the groundwater as do the 20 -year simulation results with a chloride content of around $34 \mathrm{mg} \mathrm{L}^{-1}$. It is worth noting that the propagated errors on the $\mathrm{Cl}$ content, calculated similarly to that of eq.3, never exceed $1 \mathrm{mg} \mathrm{L}^{-1}$ and thus the increase of the $\mathrm{Cl}$ content as given by the model is not impacted by the uncertainties on the calculation. The simulation after the maximum of groundwater exploitation of 20 years thus yields a $\mathrm{Cl}$ content of up to $34 \mathrm{mg} \mathrm{L}^{-1}$, including recharge, evaporation, pumping and return flow, but the maximum chloride content does not correspond to the highest $\delta^{18} \mathrm{O}$ signature as illustrated on Figure 8 for the $10^{\text {th }}$ year of aquifer exploitation. The chloride content mainly follows the aquifer-volume fluctuation, whereas the $\delta^{18} \mathrm{O}$ variations are due to the effects of three processes, i.e. pumping, evaporation and return flow, during the Rabi season. However, the increase of the $\delta^{18} \mathrm{O}$ value in the simulation is larger with the direct recharge from the first monsoon. The second monsoon has an opposite effect, the isotopic groundwater signature being more negative. Nevertheless, even if the $\delta^{18} \mathrm{O}$ signature is marked by the monsoon, the simulation again leads to the conclusion that evaporation causes enrichment in heavy isotopes. The mean $\delta^{18} \mathrm{O}$ and $\delta^{2} \mathrm{H}$ signatures are higher for the rice-paddy areas than for the other parts of the watershed, clearly showing that land-use (paddy fields, grapes, fruit, etc.), and management of the groundwater resource 
631 directly affect the hydrochemistry and isotope signatures $\left(\delta^{18} \mathrm{O}, \delta^{2} \mathrm{H}\right)$ of the groundwater,

632 notwithstanding the effect of additional anthropogenic inputs, like fertilizer applications, on the hydrochemistry.

The high $\mathrm{Cl}^{-}$contents of $<430 \mathrm{mg} . \mathrm{L}^{-1}$ (sample M20, Jan. 2006) and $370 \mathrm{mg} . \mathrm{L}^{-1}$ (sample M15, Nov. 2006) show a slight deviation from the mean weighted monsoon value in terms of $\delta^{18} \mathrm{O}$, suggesting a very small impact of the evaporation process and a large anthropogenic influence that may arise from different sources but cannot be simulated by the model (Figs. 6 and 7). In terms of input, $\mathrm{Cl}^{-}$and $\mathrm{NO}_{3}{ }^{-}$reach very high contents of around $940 \mathrm{mg}$. $\mathrm{L}^{-1}$ for $\mathrm{Cl}$ (Pauwels et al., 2007) as shown on Figure 6. The data from Sukhija et al. (2006) show a similar relationship, with most "modern" water being $\mathrm{Cl}^{-}$enriched, owing to the fact that one sample of "old" (a few hundreds to thousands of years old) water had a high $\mathrm{Cl}^{-}$content without any divergence of the $\delta^{18} \mathrm{O}$ value. When nitrates and chlorides are of organic origin, the chemical composition is marked by a lower $\mathrm{NO}_{3} / \mathrm{Cl}$ ratio than when they have a mineral source (fertilizer). This variability of the $\mathrm{NO}_{3} / \mathrm{Cl}$ ratio suggests a variety of inputs, which agrees with land use in the basin. Poultry farming and a population of 15,000 inhabitants provide organic compounds, whereas mineral fertilizer is used in paddies and vegetable gardens.

\section{Conclusions}

Stable-isotope analyses of precipitation and groundwater from a tropical hard-rock aquifer (Maheshwaram watershed, Andhra Pradesh, India) defined a detailed and dynamic picture of groundwater sources and flow paths. This endorheic watershed is representative of South Indian conditions in terms of geology (hard rock), land-use, overpumping of the hard-rock aquifer (over 700 bored open-end wells in use), and its socio-economic context. The stable isotopes revealed the following features. 

SW monsoon signals, the latter being enriched in stable isotopes compared to the first. The monsoon samples define a Local Meteoric Water Line (LMWL) that is close to the Global Meteoric Water Line (GMWL), and allow calculating the mean weighted monsoon signal.

Groundwater data collected in January allowed defining the recharge isotopic signature in the watershed that fluctuates between the two monsoons, with a shift from the LMWL due to evaporation during percolation through soil and saprolite. Groundwater from the irrigation period (March and June) plots in the same range as that defined in January, reflecting few changes at the watershed scale.

Using individual open-end wells for investigating the downscaling of water dynamics, shows that, for a moderate groundwater use for fruit- and grape growing and light industry, the data plot either close to the meteoric water lines and the mean weighted monsoon value, or on an evaporation line. The first observation suggests that recharge is rapid as the monsoon signal is not transformed during percolation through soil and saprolite, while the second observation suggests a lower recharge rate.

Open-end wells with a heavier use of groundwater for rice paddies and vegetable- and flower growing show a different functioning. Groundwater generally follows the evaporation line, with or without deviation from the mean weighted monsoon data, and a returned irrigation flow with a more evaporated signature can be identified while a mixing model allows calculating the proportion of returned water in one case.

Future work should consider variations in the hydrogeological system (layered, fractured, etc.) and in groundwater collected from different boreholes at various depths, for designing a 3D-isotopic framework. This would be necessary for identifying possible flowpaths in conjunction with a larger exploitation of the groundwater resource. Such work would also aid in generalizing the use of other isotope tools such as $\mathrm{Nd}$ and $\mathrm{Sr}$ or $\mathrm{Pb}$, and of 
newly developed isotope systematics like $\mathrm{Ca}$ or $\mathrm{Si}$, in other catchments that may face similar structural problems of groundwater overexploitation. This is of primary importance as groundwater flow and -storage in hard-rock areas are major issues for researchers and water managers, especially with regard to water quality as well as the definition of resources and aquifers and of long-term sustainability.

Acknowledgments. This study was carried out at the Indo-French Centre for Groundwater Research (BRGMNGRI). The authors thank the French Ministry of Foreign Affairs and the French Embassy in India for their support. This paper has benefited from the research and technical assistance provided by Mohamed Wajiduddin ("fabuleux Wajid"), S. Roy and F. Jouin, and from the collaboration of C. Flehoc (BRGM Mass-Spectrometer team) who made the stable-isotope analyses. Tom Bullen is warmly thanked for his comments on the first version of this paper. We are grateful to Dr. H.M. Kluijver for proofreading and editing the English text. We thank the anonymous reviewers for providing critical comments that improved this manuscript.

\section{References}

Allison, G.B., Barner, C.J., Hughes, M.W., Leaney, F.W.J. 1984. Effect of climate and vegetation on $\delta^{18} \mathrm{O}$ and $\delta$ D profiles in soils. In: Proceedings of IAEA Symposium, Vienna 1984, 105-123.

AMC, 2002. Analytical Methods Committee. Technical brief No. 10. "Fitting a linear functional relationship to data with error on both variables" (Royal Society of Chemistry).

Barth, S.R. 2000. Stable isotope geochemistry of sediments-hosted groundwater from a Late-Proterozoic-Early Mesozoic section in Central Europe. Journal of Hydrology 235, 72-87.

Ballukraya, P.N., Sakthivadivel, R. 2002. Over exploitation and artificial recharge of hard rock aquifers of South India: issues and options. IWMI-Tata Water Policy Research program, International Water Management Institute, 1-14, available at http://www.iwmi.org/iwmi-tata.

Basu, A.R., Jacobsen, S.B., Poreda, R.J., Dowling, C.B., Aggarwal, P.K. 2002. Response to Harvey, 2002: groundwater flow in the Ganges delta. Science 296, 1563.

Clark, I., Fritz, P. 1997. Environmental Isotopes in Hydrogeology. Lewis Publishers, Boca Raton, New York, $328 \mathrm{p}$.

Craig, H. 1961, Isotopic variations in meteoric waters. Science, 133, 1702.

de Condappa, D. 2005. Étude de l'écoulement d'eau à travers la Zone Non-Saturée des aquifères de socle à l'échelle spatiale du bassin versant. Application à l'évaluation de la recharge au sein du bassin versant de Maheshwaram, Andhra Pradesh, Inde. PhD thesis, University of Grenoble, 361p.

Deshpande, R.D., Bhattacharya, S.K., Jani, R.A., Gupta, S.K. 2003. Distribution of oxygen and hydrogen isotopes in shallow ground waters from Southern India: influence of a dual monsoon system. Journal of Hydrology 271, 226-239. 
De Silva, C.S., Weatherhead, E.K. 1997. Optimising the dimensions of agrowells in hard-rock aquifers in Sri Lanka. Agricultural Water Management 33, 117-126.

Detay, M., Poyet, P., Emsellem, Y. Bernardi, A. Aubrac, G. 1989. Development of the saprolite reservoir and its state of saturation: influence on the hydrodynamic characteristics of drillings in crystalline basement (in French). Compt. Rend. Acad. Sci. Paris II 309, 429-436.

Dewandel, B., Lachassagne, P., Wyns, R., Maréchal, J.C., Krishnamurthy, N.S. 2006. A generalized 3-D geological and hydrogeological conceptual model of granite aquifers controlled by single or multiphase weathering. Journal of Hydrology 330, 260-284.

Dewandel, B., Gandolfi, J.M., de Condappa, D., Ahmed, S. 2007a. An efficient methodology for estimating irrigation return flow coefficients of irrigated crops at watershed and seasonal scale. Hydrological Processes, DOI: $10.1002 /$ hyp.6738.

Dewandel, B., Gandolfi, J.M., Ahmed, S. Subrahmanyam, K. 2007b. A Decision Support Tool for sustainable Groundwater Management in semi-arid hard-rock areas with variable agro-climatic scenarios. Current Sciences 92, 1093-1102.

Fontes, J.Ch. 1980. Environmental isotopes in groundwater hydrology. Handbook of environmental isotopes geochemistry, Fritz P. and Fontes, J.Ch. (eds.), Elsevier, Amsterdam, Oxford, New York, 75-140.

Gat J.R. 2008. The isotopic composition of evaporating waters - review of the historical evolution leading up to the Craig-Gordon model. Isotopes in Environmental and Health Studies 44, 5-9.

Gibson, J.J., Sadek, M.A., Stone, D.J.M., Hughes, C.E., Hankin, S., Cendon, D.I., Hollins, S.E. 2008. Evaporative isotope enrichment as a constraint on reach water balance along a dryland river. Isotopes in Environmental and Health Studies 44, 83-98.

Gupta, C.P., Singh, V.S. 1988. Flow regime associated with partially penetrating large-diameter wells in hard rocks. Journal of Hydrology 103, 209-217.

Gupta, S.K., Deshpande, R.D. 2005. Groundwater isotopic investigations in India: What has been learned? Current Science 89, 825-835.

Gupta, S.K., Deshpande, R.D., Bhattacharya, S.K., Jani, R.A. 2005. Groundwater $\delta^{18} \mathrm{O}$ and $\delta \mathrm{D}$ from central Indian Peninsula: influence of the Arabian Sea and the Bay of Bengal branches of the summer monsoon. Journal of Hydrology 303, 38-55.

Jhajharia, D., Shrivastava, S.K., Sarkar, D., Sarkar, S. 2009. Temporal characteristics of pan evaporation trends under the humid conditions of northeast India. Agricultural and Forest Meteorology 149, 763-770.

Kattan, Z. 2008. Estimation of evaporation and irrigation return flow in arid zones using stable isotope ratios and chloride mass-balance analysis: Case of the Euphrates River, Syria. Journal of Arid Environments 72, 730-747.

Kendall, C., McDonnell, J.J. 1998. Isotope Tracers in Watershed Hydrology. Elsevier, 839p.

Kulkarni, K.M., Navada, S.V., Rao, S.M., Nair, A.R., Kulkarni, U.P., Sharma, S. 1995. Effect of the Holocene climate on composition of groundwater in parts of Haryana, India. IAEA-SM-336/36. In Proceedings of the Symposium on isotopes in water resources management, Vienna, March 1995. 439-454.

Kumar, B., Athavale, R.N., Sahay, K.S.N. 1982. Stable isotope geohydrology of the Lower Maner Basin, Andhra Pradesh, India, Journal of Hydrology 59, 315-330.

Kumar, D., Ahmed, S. 2003. Seasonal behaviour of spatial variability of groundwater level in a granitic aquifer in monsoon climate. Current Science 84, 188-196.

Lee, K.S., Kim, J.M., Lee, D.R., Kim, Y., Lee, D. 2007. Analysis of water movement through an unsaturated soil zone in Jeju Island, Korea using stable oxygen and hydrogen isotopes. Journal of Hydrology 345, 199-211. 
Majumdar, N., Majumdar, R.K., Mukherjee, A.L., Bhattacharya, S.K., Jani, R.A. 2005. Seasonal variations in the isotopes of oxygen and hydrogen in geothermal waters from Bakreswar and Tantloi, Eastern India: implications for groundwater characterization. J. Asian Earth Sci. 25, 269-278.

Mathieu, R., Bariac, T. 1996. An isotopic study $\left({ }^{2} \mathrm{H}\right.$ and $\left.{ }^{18} \mathrm{O}\right)$ of water movements in clayey soils under a semiarid climate. Water Resources Research 32, 779-789.

Maréchal J.C., Dewandel, B. Subrahmanyam. K. 2004. Contribution of hydraulic tests at different scales to characterize fracture network properties in the weathered-fissured layer of a hard rock aquifers. Water Resources Res., 40, W11508.

Maréchal, J.C., Dewandel, B., Ahmed, S., Galeazzi, L., Zaidi, F.K. 2006. Combined estimation of specific yield and natural recharge in a semi-arid groundwater basin with irrigated agriculture. Journal of Hydrology 329, 281293.

Mukherjee, A., Fryar, A.E., Rowe, H.D. 2007. Regional-scale stable isotopic signatures of recharge and deep groundwater in the arsenic affected areas of West Bengal, India. Journal of Hydrology 334, 151-161.

Murad A.A., Krishnamurthy R.V. 2008. Factors controlling stable oxygen, hydrogen and carbon isotope ratios in regional groundwater of the United Arab Emirates (UAE). Hydrological Processes 22, 1922-1931.

Nahon, D.B. 1991. Introduction to the petrology of soils and chemical weathering. J. Wiley \& Sons Ed., 313p.

Nair, A.R., Navada, S.V., Kulkarni, K.M. Kulkarni, U.P., U.P., Joseph, T.B. 1999. Environmental isotopes studies in the arid regions of western Rajasthan, India. TecDoc IAEA 1207, 41-57.

Navada, S.V., Nair, A.R., Sinha, U.K., Kulkarni, U.P., Joseph, T.B. 1999. Application of isotopes and chemistry in unsaturated zone in arid areas of Rajasthan, India. TecDoc IAEA 1246, 119-130.

Négrel, Ph., 1999. Geochemical study of a granitic area - The Margeride Mountains, France: chemical element behavior and ${ }^{87} \mathrm{Sr} /{ }^{86} \mathrm{Sr}$ constraints. Aquatic Geochemistry 5, 125-165.

Négrel, Ph., Lachassagne, P. 2000. Geochemistry of the Maroni River (French Guyana) during low water stage: Implications for water rock interaction and groundwater characteristics. Journal of Hydrology 237, 212-233.

Négrel, Ph. 2006. Water-granite interaction: clues from strontium, neodymium and rare earth elements in saprolite, sediments, soils, surface and mineralized waters. Applied Geochemistry 21, 1432-1454.

Négrel, Ph., Dewandel, B., Gandolfi, J.M., Dayal, A.M., Pauwels, H., Roy, S., Flehoc, C. 2007. Stable isotope hydrogeology of the Maheshwaram watershed (Andra Pradesh, India). $3^{\text {rd }}$ International Groundwater Conference (IGC-2007) on Water, Environment and Agriculture, Feb. 7-10, 2007, Combinatore, India. In Groundwater Resources Assessment, Recharge and Management, Macmillan Advanced Research Series, M.V. Ranghaswami, K. Palanisami, C. Mayilswami eds., 214-221.

Négrel, Ph., Machard de Gramont, H., Lemière, B., Billaud, P., Sengupta, B. 2007. Hydrogeochemical processes, mixing and isotope tracing in hard rock aquifers and surface waters from the Subarnarekha river basin, (east Singhbhum district, Jharkhand state, India). Hydrogeology Journal 15, 1535-1552.

Pauwels, H., Roy, S., Négrel, Ph., Ahmed, S., Dewandel, B., Gandolfi, J.M., Atal, S. 2007. Genesis and control of fluoride concentrations in groundwater of a small agricultural watershed (Maheswharam, Andhra Pradesh, India). 3rd International Groundwater Conference (IGC-2007) on Water, Environment and Agriculture, Feb. 710, 2007, Combinatore, India. In Groundwater Quality and Environment, Macmillan Advanced Research Series, M.V Ranghaswami, K. Palanisami, C. Mayilswami eds., 158-164.

Perrin, J., Dewandel, B., Aulong, S., Ahmed, S., Hrkal, Z., Krazny, J., Mascre, C., Massuel, S., Mukherji, A., Samad, M. 2006. SUSTWATER Project Final Scientific Report. BRGM report RP-56913-FR, 137 p.

Praamsma, T., Novakowski, K., Kyser, K., Hall, K. 2009. Using stable isotopes and hydraulic head data to investigate groundwater recharge and discharge in a fractured rock aquifer. Journal of Hydrology 366, 35-45. 
Robins, N.S., Smedley, P.L. 1994. Hydrogeology and hydrogeochemistry of a small hard-rock island - the heavily stressed aquifer of Jersey. Journal of Hydrology 163, 249-269.

Sami, K. 1992. Recharge mechanisms and geochemical processes in a semi-arid sedimentary basin, Eastern Cape, South Africa. Journal of Hydrology 139, 27-48.

Simpson, H.J., Herczeg, A.L., Meyer, W.S. 1992. Stable isotope ratios in irrigation water can estimate rice crop evaporation. Geophysical Research Letters 19, 377-380.

Singhal, D.C., Niwas, S., Singhal, B.B.S. 1988. Integrated approach to aquifer delineation in hard rock terrainsA case study from the Banda District, India. Journal of Hydrology 98, 165-183.

Sukhija, B.S., Reddy, D.V., Nagabhushanam, P. 1998. Isotopic fingerprints of paleoclimates during the last 30,000 years in deep confined groundwaters of Southern India. Quaternary Research 50, 252-260.

Sukhija, B.S., Reddy, D.V., Nagabhushanam, P., Bhattacharya, S.K., Jani, R.A., Kumar, D. 2006. Characterisation of recharge processes and groundwater flow mechanisms in weathered-fractured granites of Hyderabad (India) using isotopes. Hydrogeology Journal 14, 663-674.

Tardy, Y. 1971. Characterization of the principal weathering types by the geochemistry of waters from some European and African crystalline massifs. Chemical Geology 7, 253-271.

Taylor, R., Howard, K. 2000. A tectono-geomorphic model of the hydrogeology of deeply weathered crystalline rock: evidence from Uganda. Hydrogeology Journal. 8, 279-294.

Tirumalesh, K., Shivanna, K., Jalihal, A.A. 2006. Isotope hydrochemical approach to understand fluoride release into groundwaters of Ilkal area, Bagalkot District, Karnataka, India. Hydrogeology Journal 15, 589-598.

Wyns, R., Gourry, J.C., Baltassat, J.M., Lebert, F. 1999. Caractérisation multiparamètres des horizons de subsurface $(0-100 \mathrm{~m})$ en contexte de socle altéré, in $2^{\text {ème }}$ Colloque GEOFCAN, edited by I. BRGM, IRD, UPMC, pp. 105-110, Orléans, France.

Zheng, Y., Datta, S., Stute, M., Dhar, R., Hoque, M.A., Rahman, M.W., Ahmed, K.M., Schlosser, P., van Geen, A. 2005. Stable isotopes $\left({ }^{18} \mathrm{O},{ }^{2} \mathrm{H}\right)$ and arsenic distribution in the shallow aquifers in Araihazar, Bangladesh. EOS Transactions American Geophysical Union, 86 (52), Fall Meeting Supplement, Abstract H31B-1305.

\section{Figure and table captions}



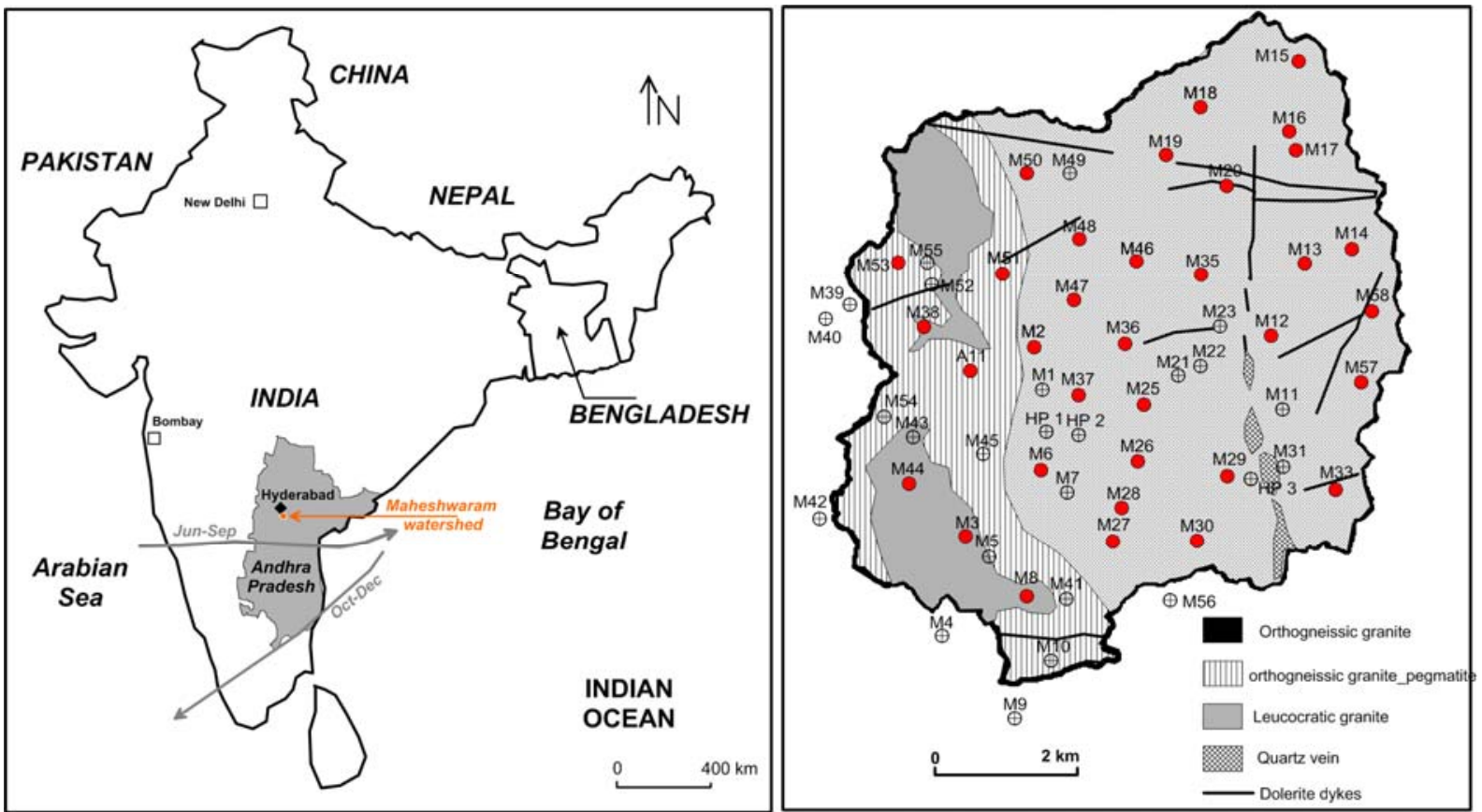

Figure 1. Location of the Maheshwaram watershed (located $35 \mathrm{~km}$ south of Hyderabad) in Andhra Pradesh (India), grey arrows indicate the main wind direction (and monsoon origin) for the periods June to September and October to December (Deshpande et al., 2003). Simplified geological map of the Maheshwaram watershed with location of sampled boreholes (Mxx). Black triangle: rain gauge in Maheshwaram village. 


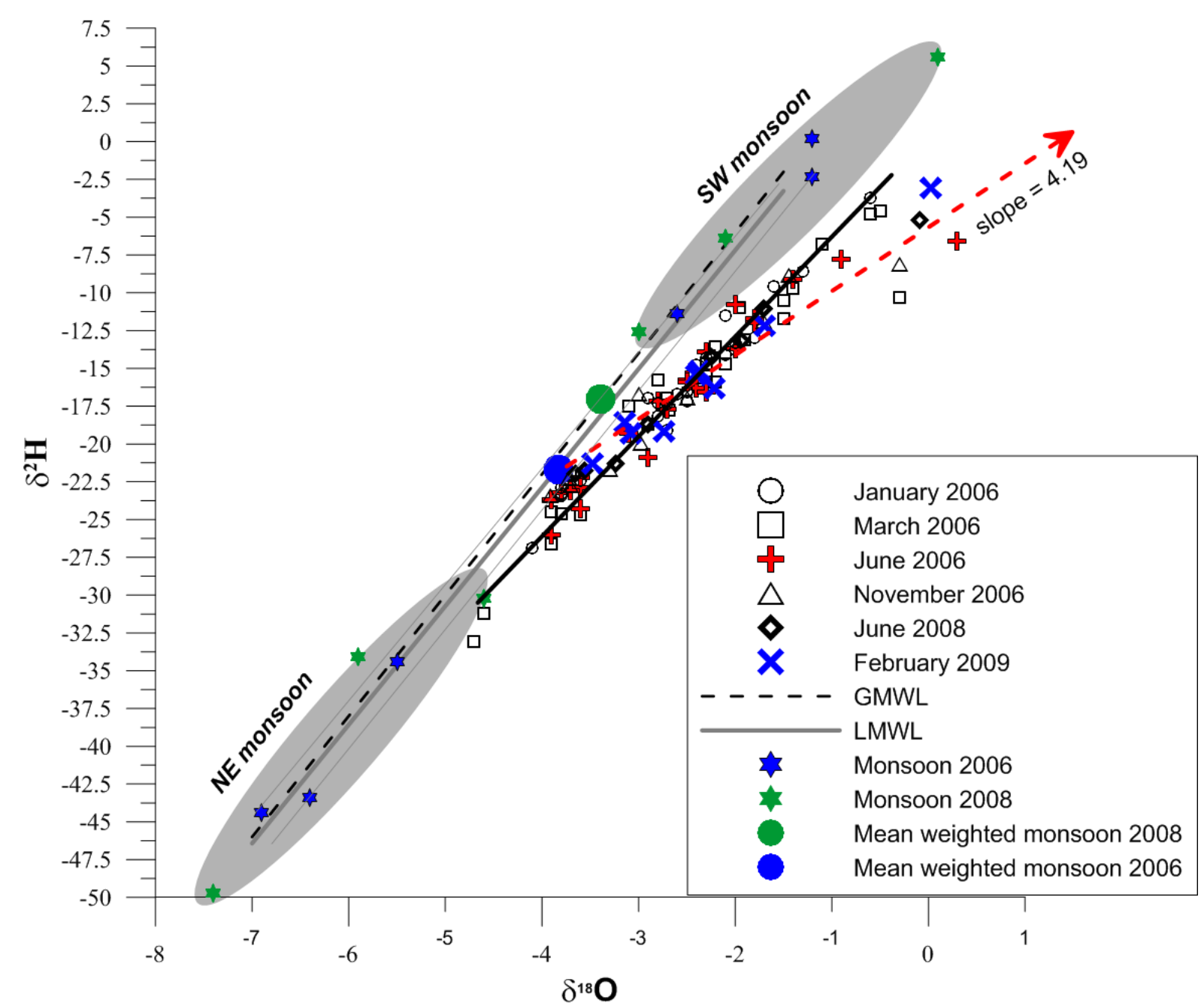

Figure 2. $\delta^{18} \mathrm{O}-\delta^{2} \mathrm{H}$ plot for groundwater from the Maheshwaram watershed in January (Fig. 2), March, June and

894 November 2006, June 2008 and February 2009. GMWL is the global meteoric water line $\left(\delta^{2} \mathrm{H}=8 \delta^{18} \mathrm{O}+10\right.$; Craig, 1961). LMWL is the local meteoric water line defined in this study shown with its $95 \%$ uncertainty envelopes. $\delta^{18} \mathrm{O}-\delta^{2} \mathrm{H}$ monsoon samples and weighted means are shown for 2006 and 2008 monsoons. The monsoon data (Kumar et al., 1982) are from the Lower Maner Basin (Andhra Pradesh, north of Maheshwaram). Groundwater in the watershed collected in January 2006 defines a co-variation (black line), the equation is $\delta^{2} \mathrm{H}=6.17 \pm 0.25 \times \delta^{18} \mathrm{O}-0.54 \pm 0.67(\mathrm{n}=24)$. 

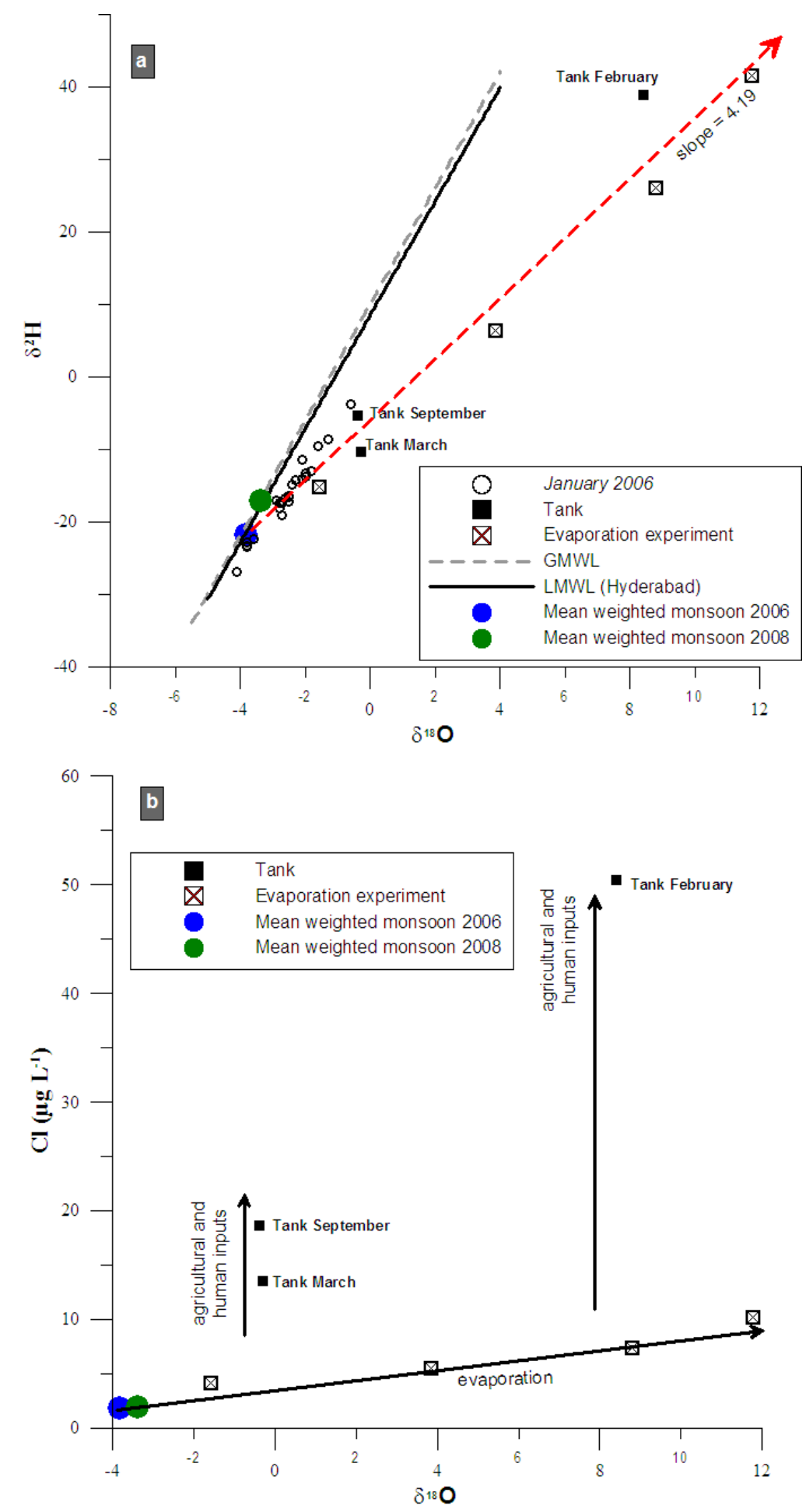

Figure 3. $\delta^{18} \mathrm{O}-\delta^{2} \mathrm{H}$ plot for groundwater from the Maheshwaram watershed in January (Fig. 4a) and pan-

902 evaporation experiment (Fig. 4b). Tank-sample data are from the only surface water in the watershed. GMWL,

903 LMWL, and monsoon, mean-weighted-monsoon as on Figure 2. $\delta^{18} \mathrm{O}-\mathrm{Cl}$ content plot of pan-evaporation experiment; mean-weighted-monsoon and tank surface water. 


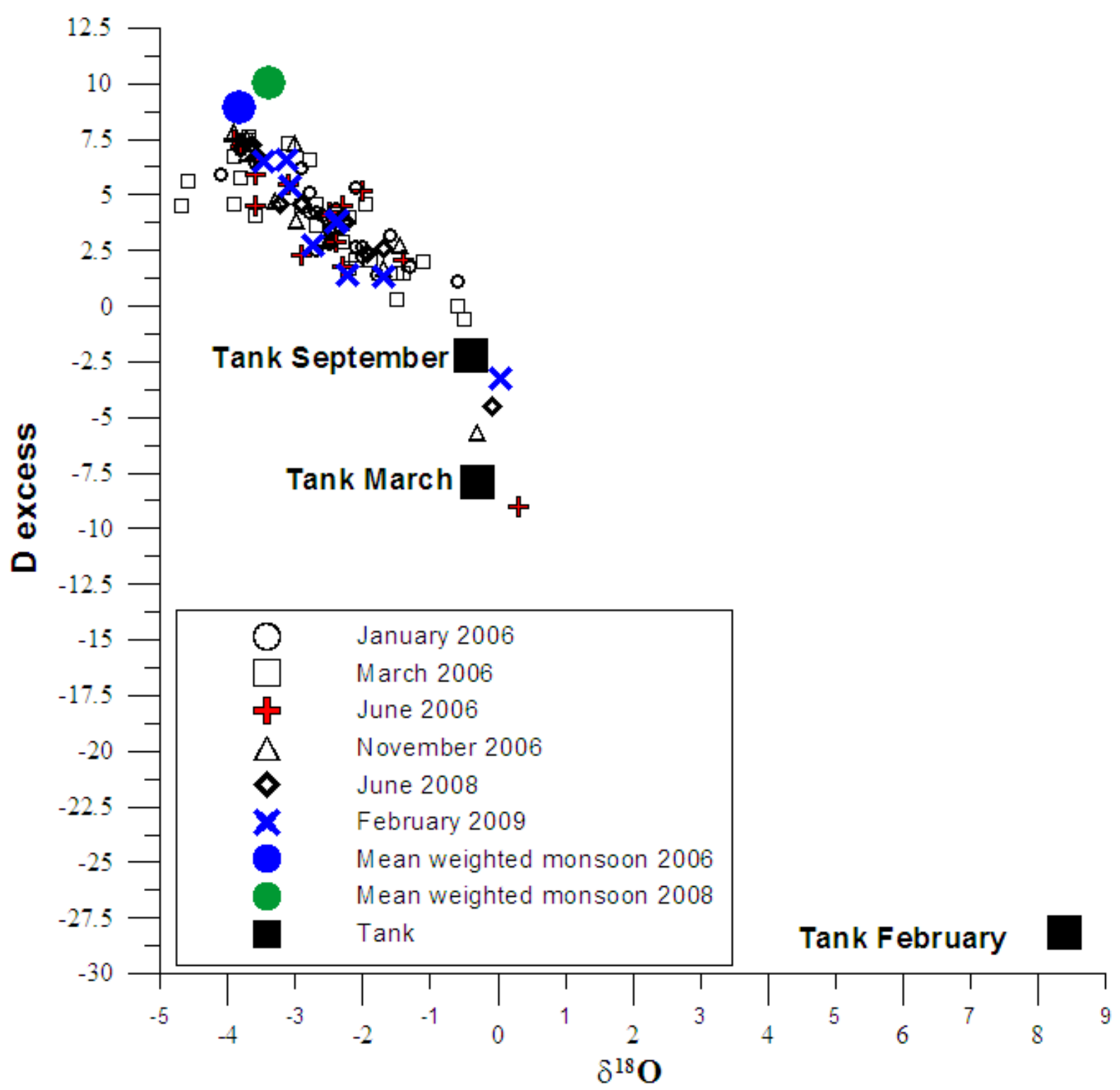

906 Figure 4, 'D-excess' vs. $\delta^{18} \mathrm{O}$ plot for groundwater from the Maheshwaram watershed and for the monsoons (see 907 text). 

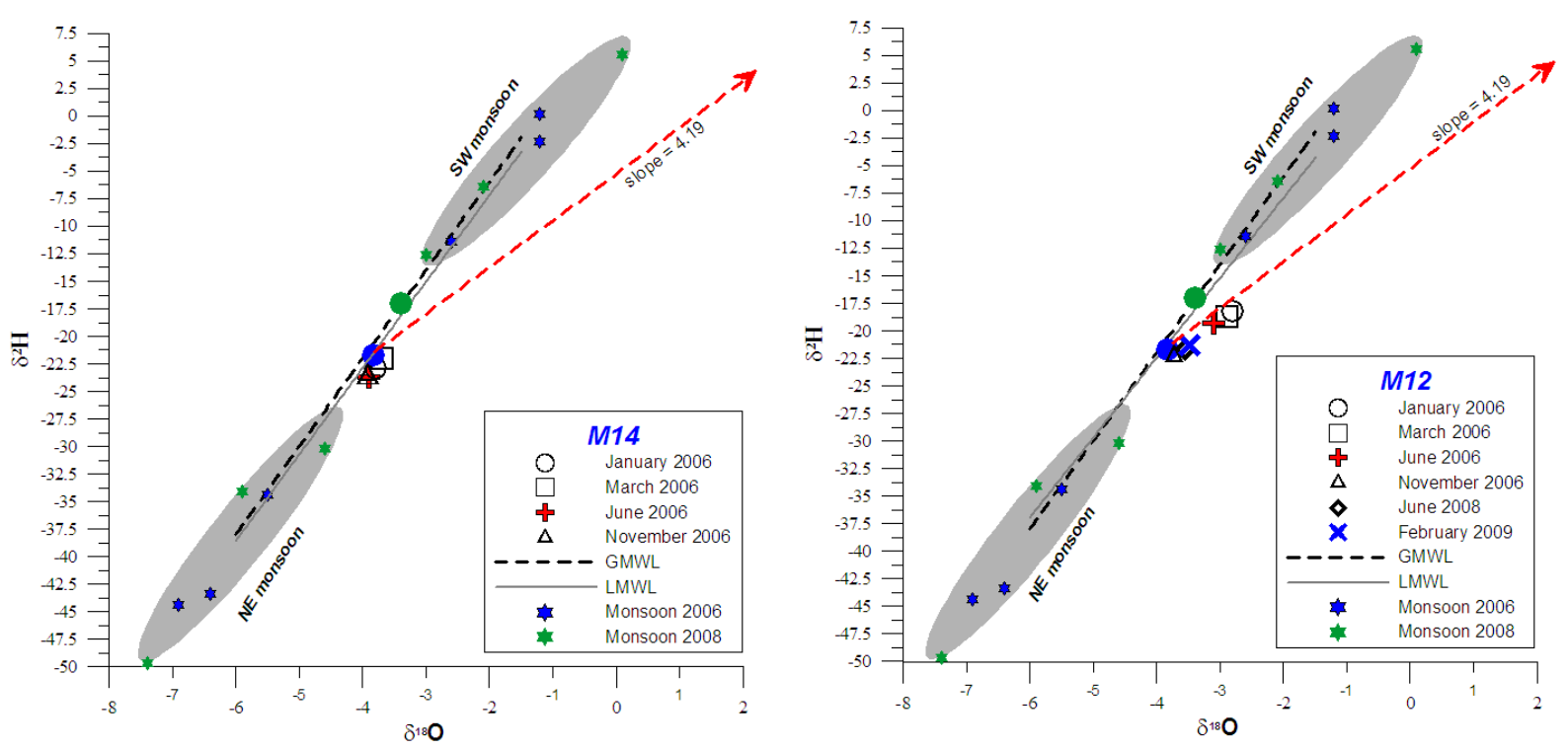

908

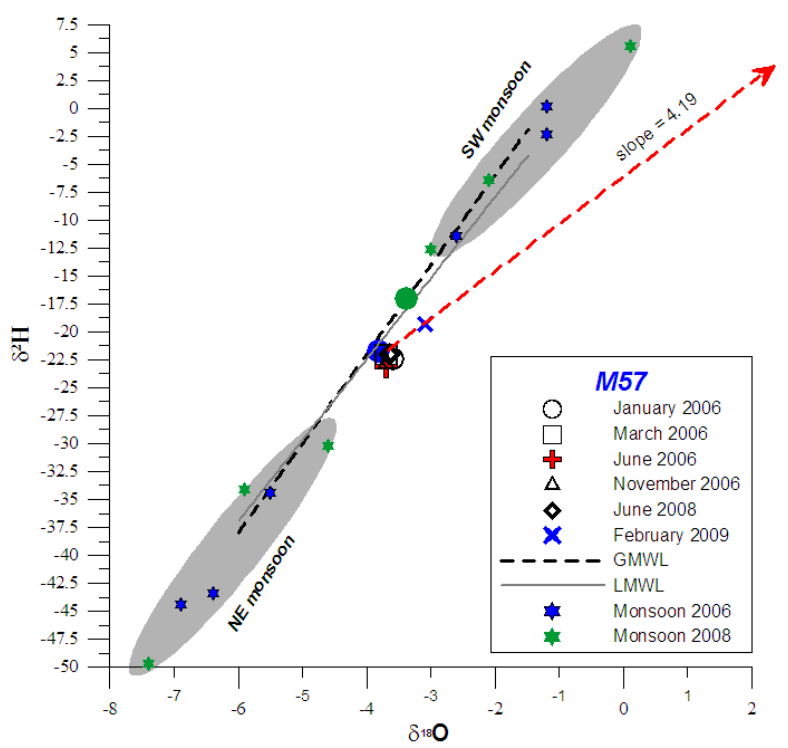



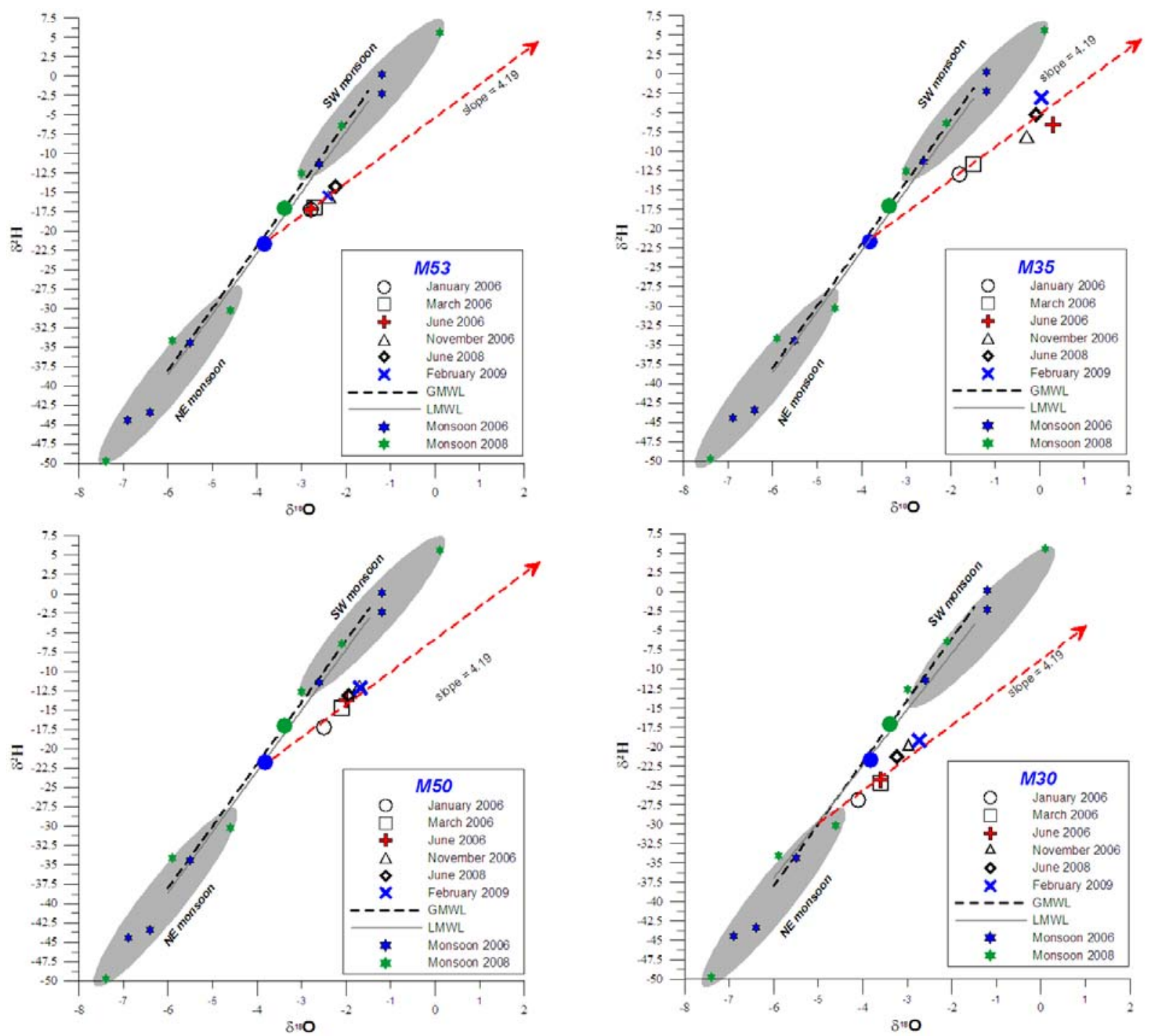

Figure 5a, b. Seasonal $\delta^{18} \mathrm{O} v s . \delta^{2} \mathrm{H}$ variations for selected groundwater collected in the Maheshwaram watershed

911 (moderate use of groundwater for cultivation through open-end wells M12, 14 and 57 and greater use of

912 groundwater through open-end wells M30, 35, 50 and 53; the monsoon, mean-weighted-monsoon, and the slope

913 of the evaporation line are shown as well. As on Figures 2 and 3, GMWL is the global meteoric water line and

914 LMWL is the local meteoric water line. 


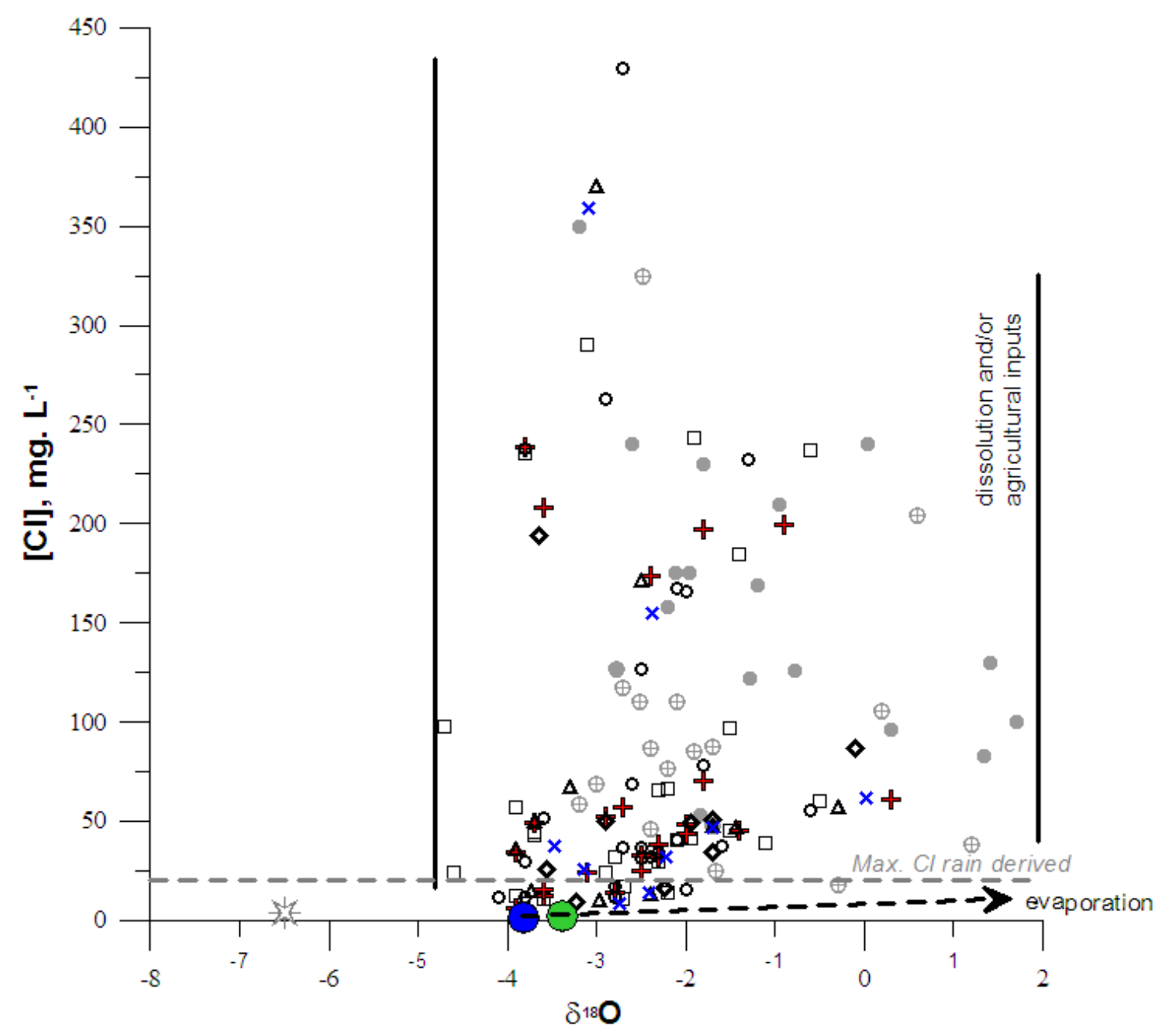

Figure 6. $\mathrm{Cl}^{-}$concentration vs. $\delta^{18} \mathrm{O}$ plot for groundwater from the Maheshwaram watershed, including data for

917 the monsoon, and from the study by Sukhija et al. (2006) in the catchment that comprises Hyderabad and its

918 suburbs. Dashed line corresponds to the one-step evaporation line following the evaporation experiment. 


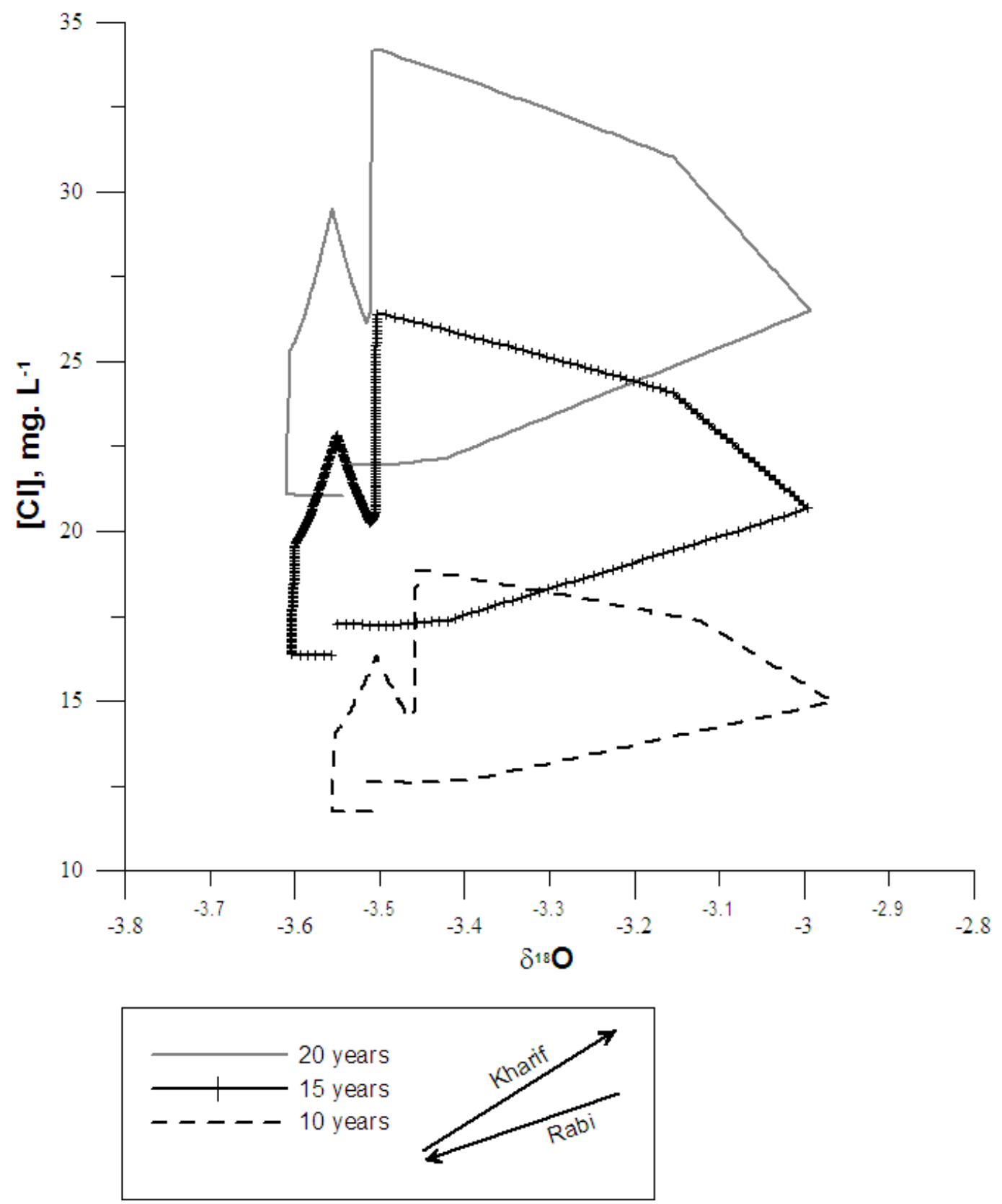

Figure 7. Results of the simulation for Cl- contents and $\delta^{18} \mathrm{O}$ signatures over a period of 20 years within the

921 Maheshwaram catchment, considering yearly evolution at 10,15 and 20 years of overpumping of the aquifer. 


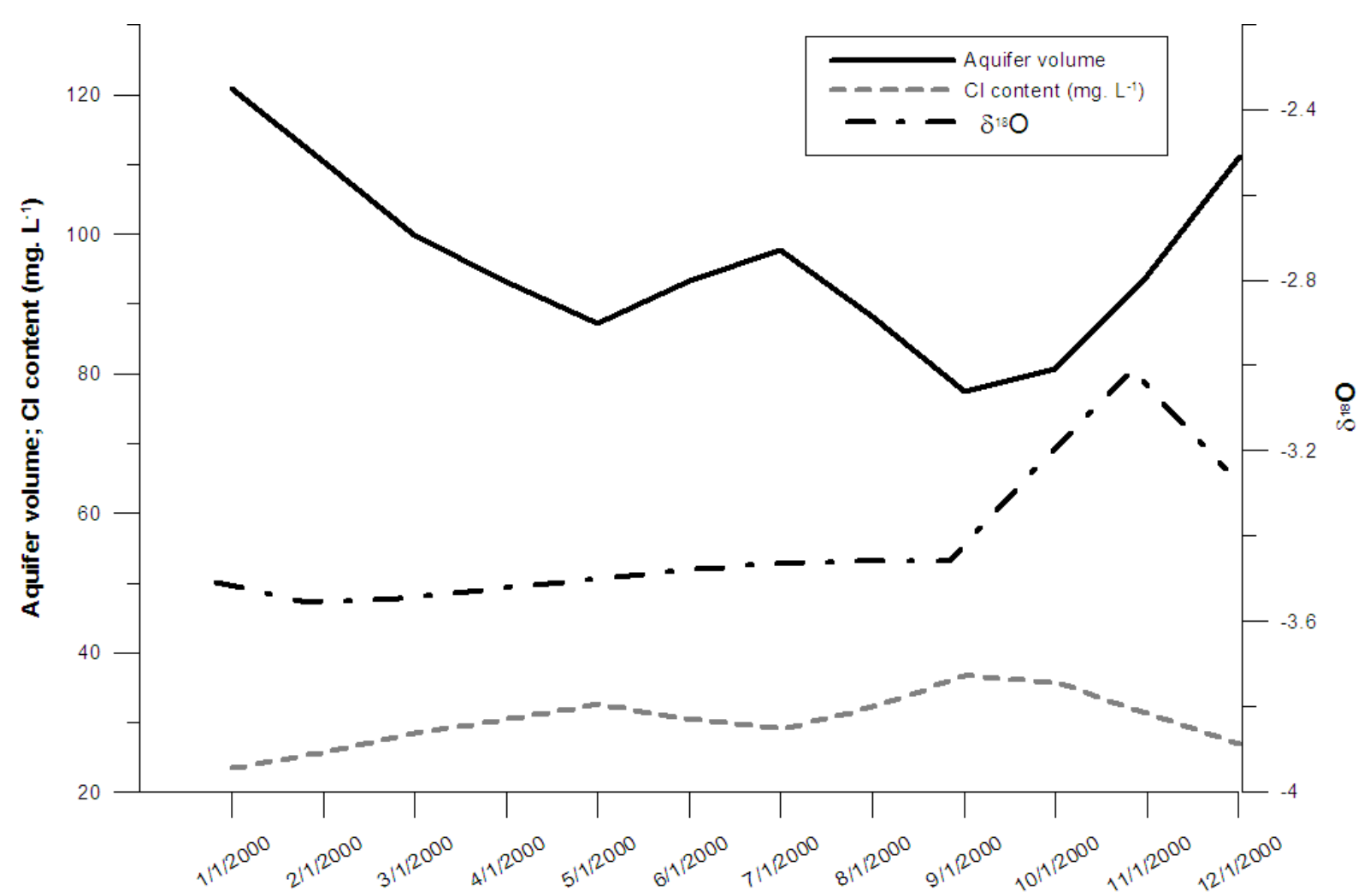

Figure 8. Evolution along the 10th year of overpumping of the Maheshwaram aquifer, for aquifer volume, $\mathrm{Cl}$ 924 content, and $\delta^{18} \mathrm{O}$ *** 


\begin{tabular}{|c|c|c|c|c|c|}
\hline Period & $\delta^{2} \mathrm{H} \%$ & $\delta^{18} \mathrm{O} \%$ & $\begin{array}{c}\text { Collected } \\
\text { volume Rainfall } \\
\text { gauge }\end{array}$ & $\begin{array}{c}\text { Collected } \\
\text { volume Meteo } \\
\text { gauge }\end{array}$ & $\mathrm{Cl}^{-}$ \\
\hline & V-SMOW $( \pm 0.8 \%)$ & V-SMOW $( \pm 0.1 \%$ ) & $\mathrm{L}$ & $\mathrm{L}$ & $\mathrm{mg} \cdot \mathrm{L}^{-1}$ \\
\hline \multicolumn{6}{|l|}{ Monsoon 2006} \\
\hline June 2006 & -2.3 & -1.2 & 0.70 & 0.60 & 4.75 \\
\hline July 2006 & -11.4 & -2.6 & 1.75 & 1.50 & 2.10 \\
\hline August 2006 & 0.2 & -1.2 & 3.50 & 2.94 & 1.53 \\
\hline September 2006 & -43.4 & -6.4 & 4.00 & 4.18 & 1.30 \\
\hline October 2006 & -44.4 & -6.9 & 0.80 & 0.77 & 2.55 \\
\hline November 2006 & -34.4 & -5.5 & 0.25 & 0.40 & 3.30 \\
\hline $\begin{array}{l}\text { Mean weighted monsoon } \\
2006\end{array}$ & -21.69 & -3.83 & - & - & 1.86 \\
\hline \multicolumn{6}{|l|}{ Monsoon 2008} \\
\hline June 2008 & 5.6 & 0.1 & 0.75 & - & nd \\
\hline July 2008 & -6.4 & -2.1 & 2.84 & - & nd \\
\hline August 2008 & -12.6 & -3 & 5.30 & - & nd \\
\hline September 2008 & -49.7 & -7.4 & 1.45 & - & nd \\
\hline October 2008 & -30.2 & -4.6 & 1.25 & - & nd \\
\hline November 2008 & -34.1 & -5.9 & 0.40 & - & nd \\
\hline $\begin{array}{l}\text { Mean weighted monsoon } \\
2008\end{array}$ & -17.05 & -3.39 & - & - & - \\
\hline
\end{tabular}

Table 1. Results of stable isotopes of the water molecule $\left(\delta^{18} \mathrm{O}\right.$ and $\left.\delta^{2} \mathrm{H}\right)$, collected volumes, and $\mathrm{Cl}^{-}$contents for monsoon precipitation collected in Maheshwaram village in 2006. 


\begin{tabular}{|c|c|c|c|c|c|c|}
\hline Sample & $\begin{array}{l}\mathbf{T} \\
{ }^{\circ} \mathrm{C}\end{array}$ & $\begin{array}{c}\text { EC } \\
\mu \mathrm{S} \mathrm{cm}^{-1}\end{array}$ & $\begin{array}{c}\mathrm{Cl}^{-} \\
\mathrm{mg} \cdot \mathrm{L}^{-1}\end{array}$ & $\begin{array}{c}\delta^{2} \mathbf{H} \\
\% \circ \text { V-SMOW }( \pm 0.8 \%)\end{array}$ & $\begin{array}{c}\delta^{18} \mathbf{O} \\
\% \text { V-SMOW }( \pm 0.1 \%)\end{array}$ & D-excess \\
\hline \multicolumn{7}{|c|}{ January 2006} \\
\hline A11 & 27.5 & 850 & 34.41 & -14.3 & -2.3 & 4.1 \\
\hline M02 & 28.4 & 1440 & 166.22 & -13.3 & -2.0 & 2.7 \\
\hline M03 & 27.2 & 770 & 40.64 & -11.5 & -2.1 & 5.3 \\
\hline M06 & 29.8 & 685 & 36.98 & -19.1 & -2.7 & 2.5 \\
\hline M08 & 26.6 & 700 & 37.58 & -9.6 & -1.6 & 3.2 \\
\hline M12 & 26.0 & 750 & 17.34 & -18.2 & -2.8 & 4.2 \\
\hline M14 & 27.6 & 900 & 29.75 & -22.9 & -3.8 & 7.5 \\
\hline M15 & 27.9 & 3310 & 263.21 & -17.0 & -2.9 & 6.2 \\
\hline M16 & 27.3 & 1800 & 238.00 & -23.4 & -3.8 & 7.0 \\
\hline M19N & 27.4 & 1470 & 167.04 & -14.1 & -2.1 & 2.7 \\
\hline M20 & 27.5 & 3570 & 429.15 & -17.4 & -2.7 & 4.2 \\
\hline M25 & 28.1 & 700 & 31.45 & -16.6 & -2.5 & 3.4 \\
\hline M28 & 26.6 & 670 & 15.65 & -13.8 & -2.0 & 2.2 \\
\hline M29 & 25.9 & 1390 & 126.84 & -16.5 & -2.5 & 3.5 \\
\hline M30 & 26.3 & 670 & 11.70 & -26.9 & -4.1 & 5.9 \\
\hline M33 & 27.7 & 600 & 11.78 & -23.3 & -3.8 & 7.1 \\
\hline M35N & 27.1 & 1060 & 77.91 & -13.0 & -1.8 & 1.4 \\
\hline M36N & 28.8 & 750 & 31.86 & -14.8 & -2.4 & 4.4 \\
\hline M44 & 26.7 & 940 & 55.77 & -3.7 & -0.6 & 1.1 \\
\hline M46 & 29.3 & 800 & 68.91 & -16.7 & -2.6 & 4.1 \\
\hline M50 & 26.9 & 770 & 36.82 & -17.2 & -2.5 & 2.8 \\
\hline M51 & 27.3 & 1830 & 232.62 & -8.6 & -1.3 & 1.8 \\
\hline M53 & 28.4 & 810 & 11.35 & -17.3 & -2.8 & 5.1 \\
\hline M57 & 28.6 & 1100 & 51.66 & -22.4 & -3.6 & 6.4 \\
\hline \multicolumn{7}{|l|}{ March 2006} \\
\hline A11 & 27.4 & 820 & 29.62 & -15.5 & -2.3 & 2.9 \\
\hline M02 & 28.5 & 970 & 97.91 & -33.1 & -4.7 & 4.5 \\
\hline M03 & 26.8 & 800 & 41.12 & -11.0 & -2.0 & 4.6 \\
\hline M06 & 28.6 & 800 & 45.50 & -10.5 & -1.5 & 1.5 \\
\hline M08 & 27.0 & 660 & 38.97 & -6.8 & -1.1 & 2.0 \\
\hline M12 & 26.5 & 797 & 24.30 & -18.7 & -2.9 & 4.5 \\
\hline M14 & 27.6 & 940 & 42.89 & -22.0 & -3.7 & 7.6 \\
\hline M15 & 28.8 & 3270 & 290.07 & -17.5 & -3.1 & 7.3 \\
\hline M16 & nd & 1780 & 235.28 & -24.6 & -3.8 & 5.8 \\
\hline M19N & 27.1 & 180 & 243.59 & -13.1 & -1.9 & 2.1 \\
\hline M20 & 29.1 & 1077 & 57.17 & -26.6 & -3.9 & 4.6 \\
\hline M25 & 29.1 & 590 & 17.43 & -17.8 & -2.7 & 3.7 \\
\hline M28 & 27.8 & 690 & 13.84 & -13.6 & -2.2 & 4.0 \\
\hline M29 & 26.8 & 930 & 66.32 & -15.9 & -2.2 & 1.7 \\
\hline M30 & 27.5 & 1460 & 10.81 & -24.7 & -3.6 & 4.1 \\
\hline M33 & 28.2 & 610 & 12.18 & -24.5 & -3.9 & 6.7 \\
\hline M35N & 27.4 & 1140 & 96.80 & -11.7 & -1.5 & 0.3 \\
\hline M36N & 28.6 & 760 & 31.96 & -15.8 & -2.8 & 6.6 \\
\hline M37 & 28.6 & 1490 & 237.33 & -4.8 & -0.6 & 0.0 \\
\hline M44 & 26.0 & 940 & 60.41 & -4.6 & -0.5 & -0.6 \\
\hline M46 & 28.6 & 790 & 65.34 & -14.7 & -2.3 & 3.7 \\
\hline M48 & 27.5 & 650 & 24.46 & -31.2 & -4.6 & 5.6 \\
\hline M50 & 27.4 & 650 & 40.37 & -14.7 & -2.1 & 2.1 \\
\hline M51 & 27.5 & 1770 & 184.74 & -9.7 & -1.4 & 1.5 \\
\hline M53 & 28.0 & 790 & 10.72 & -17.0 & -2.7 & 4.6 \\
\hline M57 & 30.1 & 1080 & 44.79 & -22.1 & -3.7 & 7.5 \\
\hline Tank & nd & nd & nd & -10.3 & -0.3 & -7.9 \\
\hline
\end{tabular}




\begin{tabular}{|c|c|c|c|c|c|c|}
\hline A11 & 28.8 & 790 & 31.73 & -13.9 & -2.3 & 4.5 \\
\hline M2 & nd & nd & 173.78 & -16.3 & -2.4 & 2.9 \\
\hline M3 & 28.2 & 840 & 48.85 & -10.8 & -2.0 & 5.2 \\
\hline M6 & 27.2 & 690 & 38.51 & -16.6 & -2.3 & 1.8 \\
\hline M8 & nd & nd & 45.31 & -9.1 & -1.4 & 2.1 \\
\hline M12 & nd & nd & 24.62 & -19.3 & -3.1 & 5.5 \\
\hline M14 & 28.6 & 890 & 34.30 & -23.7 & -3.9 & 7.5 \\
\hline M15 & 28.9 & 1480 & 208.46 & -22.2 & -3.6 & 6.6 \\
\hline M16 & 27.8 & 1740 & 238.38 & -23.2 & -3.8 & 7.2 \\
\hline M25 & 28.3 & 650 & 25.28 & -15.8 & -2.5 & 4.2 \\
\hline M29 & nd & nd & 52.53 & -20.9 & -2.9 & 2.3 \\
\hline M30 & 27.5 & 720 & 12.56 & -24.3 & -3.6 & 4.5 \\
\hline M33 & 28.2 & 640 & 15.82 & -22.9 & -3.6 & 5.9 \\
\hline M35N & nd & nd & 60.69 & -6.6 & 0.3 & -9.0 \\
\hline M36N & 29.0 & 780 & 32.59 & -15.9 & -2.5 & 4.1 \\
\hline M37 & 28.7 & 1160 & 199.16 & -7.8 & -0.9 & -0.6 \\
\hline M44 & nd & nd & 70.63 & -11.7 & -1.8 & 2.7 \\
\hline M46 & 28.7 & 756 & 57.27 & -17.7 & -2.7 & 3.9 \\
\hline M48 & nd & nd & 6.14 & -26.0 & -3.9 & 5.2 \\
\hline M50 & nd & nd & 43.66 & -13.7 & -2.0 & 2.3 \\
\hline M51 & 27.4 & 1610 & 197.50 & -12.0 & -1.8 & 2.4 \\
\hline M53 & 28.9 & 810 & 13.90 & -17.2 & -2.8 & 5.2 \\
\hline M57 & 28.8 & 1060 & 49.27 & -23.1 & -3.7 & 6.5 \\
\hline \multicolumn{7}{|c|}{ November 2006} \\
\hline M2 & 28.3 & 1940 & 170.28 & -17.0 & -2.5 & 3.0 \\
\hline M8 & nd & $\mathrm{Nd}$ & 45.74 & -8.8 & -1.4 & 2.7 \\
\hline M12 & nd & $\mathrm{Nd}$ & 13.72 & -22.3 & -3.7 & 7.5 \\
\hline M14 & nd & $\mathrm{Nd}$ & 34.95 & -23.4 & -3.9 & 7.8 \\
\hline M15 & 28.2 & 4930 & 369.61 & -16.7 & -3.0 & 7.3 \\
\hline M29 & 27.5 & 1350 & 66.52 & -21.7 & -3.3 & 4.7 \\
\hline M30 & nd & $\mathrm{Nd}$ & 9.48 & -20.0 & -3.0 & 3.8 \\
\hline M35 & nd & 1280 & 56.70 & -8.1 & -0.3 & -5.7 \\
\hline M50 & 27.4 & 1300 & 46.58 & -11.9 & -1.7 & 1.7 \\
\hline M53 & 28.9 & 1120 & 12.29 & -15.6 & -2.4 & 3.6 \\
\hline M57 & nd & nd & 49.47 & -22.8 & -3.7 & 6.9 \\
\hline \multicolumn{7}{|c|}{ June 2008} \\
\hline M6 & 27.9 & nd & 34.10 & -11.0 & -1.7 & 2.6 \\
\hline M8 & 28.7 & 780 & 51.15 & -11.0 & -1.7 & 2.6 \\
\hline M12 & 29.2 & 700 & 25.73 & -21.7 & -3.6 & 6.7 \\
\hline M30 & 28.3 & 700 & 9.66 & -21.3 & -3.2 & 4.6 \\
\hline M35 & 27.7 & 1200 & 86.44 & -5.2 & -0.1 & -4.5 \\
\hline M48 & 28.4 & nd & 50.41 & -18.7 & -2.9 & 4.6 \\
\hline M50 & 27.7 & 920 & 49.10 & -13.2 & -1.9 & 2.3 \\
\hline M53 & 30.1 & 870 & 16.55 & -14.2 & -2.2 & 3.7 \\
\hline M57 & 30.6 & 1510 & 194.06 & -22.0 & -3.7 & 7.2 \\
\hline \multicolumn{7}{|c|}{ February 2009} \\
\hline M2 & 28.8 & 1303 & 154.71 & -15.2 & -2.4 & 3.8 \\
\hline M6 & 27.6 & 752 & 31.73 & -16.3 & -2.2 & 1.4 \\
\hline M8 & 23 & 596 & 25.88 & -18.6 & -3.1 & 6.5 \\
\hline M12 & 28.6 & 763 & 37.30 & -21.3 & -3.5 & 6.5 \\
\hline M30 & 27.7 & 683 & 8.40 & -19.1 & -2.7 & 2.7 \\
\hline M35 & 27.5 & 1085 & 61.65 & -3.0 & 0.0 & -3.3 \\
\hline M50 & 26.9 & 982 & 46.83 & -12.2 & -1.7 & 1.3 \\
\hline M53 & 29.6 & 857 & 14.00 & -15.4 & -2.4 & 3.8 \\
\hline M57 & 32 & 2000 & 359.01 & -19.3 & -3.1 & 5.4 \\
\hline
\end{tabular}




$\begin{array}{ccccccc}\text { Tank March 2006 } & \text { nd } & \text { nd } & 13.6 & -10.3 & -0.3 & -7.9 \\ \text { Tank November 2006 } & \text { nd } & \text { nd } & 18.7 & -5.4 & -0.4 & -2.2 \\ \text { Tank February 2009 } & \text { nd } & \text { nd } & 50.42 & 38.4 & 8.4 & -28.2\end{array}$

nd $=$ non-determined values

959

960 Table 2. Results of field variables $\left(\mathrm{EC}\right.$ in $\mu \mathrm{S} / \mathrm{cm}$; temperature in $\left.{ }^{\circ} \mathrm{C} ; \mathrm{pH}\right)$ and stable isotopes of the water 961 molecule $\left(\delta^{18} \mathrm{O}\right.$ and $\left.\delta^{2} \mathrm{H}\right)$, in \%o with reference to V-SMOW (Vienna Standard Mean Ocean Water) for 962 groundwater collected in the Maheshwaram watershed. 


\begin{tabular}{|l|l|c|c|}
\hline \multicolumn{1}{|c|}{ Period } & \multicolumn{1}{|c|}{ Equation } & n & $\mathbf{R}^{2}$ \\
\hline January 2006 & $\delta^{2} \mathrm{H}=6.17 \pm 0.25 \times \delta^{18} \mathrm{O}-0.54 \pm$ & 24 & $>0.98$ \\
& 0.67 & & \\
\hline March 2006 & $\delta^{2} \mathrm{H}=6.44 \pm 0.18 \times \delta^{18} \mathrm{O}-0.24 \pm 0.50$ & 26 & $>0.98$ \\
\hline June 2006 & $\delta^{2} \mathrm{H}=5.30 \pm 0.19 \times \delta^{18} \mathrm{O}-3.33 \pm 0.54$ & 23 & $>0.98$ \\
\hline November 2006 & $\delta^{2} \mathrm{H}=4.80 \pm 0.43 \times \delta^{18} \mathrm{O}-4.49 \pm 1.22$ & 11 & $>0.98$ \\
\hline June 2008 & $\delta^{2} \mathrm{H}=5.11 \pm 0.30 \times \delta^{18} \mathrm{O}-3.44 \pm$ & 9 & $>0.98$ \\
& 0.77 & 9 & $>0.98$ \\
\hline February 2009 & $\delta^{2} \mathrm{H}=5.16 \pm 0.32 \times \delta^{18} \mathrm{O}-3.51 \pm$ & & \\
& 0.81 & & \\
\hline
\end{tabular}

996

997 Table 3. Results of $\delta^{18} \mathrm{O}$ and $\delta^{2} \mathrm{H}$ relationships for the January, March, June and November 2006, June 2008,

998 February 2009 collection periods, $\mathrm{n}$ is the number of open end wells collected and $\mathrm{R}^{2}$ is the correlation 999 coefficient.

1000

1001

1002

1003 